\title{
Price Responsiveness of Shale Oil: A Bakken Case Study
}

\author{
Marc H. Vatter $\oplus^{1,2,5}$ Samuel A. VanVactor, ${ }^{3}$ and Timothy C. Coburn ${ }^{4}$
}

Received 26 March 2021; accepted 27 October 2021 Published online: 24 January 2022

We estimated oil supply from hydraulically fractured horizontal wells completed in North Dakota from March 2015 through May 2019. We modeled impacts on production of price, capital costs, technological progress, well-to-well interference, and location. Two models were developed: One considered production to be a continuous stream (omitting gaps) and the other allowed that production may be discontinuous, with starts, shut-ins, and re-starts. Both gave estimates of price elasticity higher than that of non-OPEC oil supply in general. We confirmed the rapid decline rates from early peaks that characterize shale wells and demonstrated that, although various factors can shift production up or down, the decline rate remains consistent. Given this, and a much shorter development time, shale oil can be ramped up and down more quickly than conventional oil in North America today. Consequently, the price response of shale oil tends to dampen the long-term price cycle and moderate the price shocks that have plagued the market, and the macroeconomy.

KEY WORDS: Bakken Shale oil, panel data, continuous and non-continuous production, decline rate, supply price elasticity, technological or experiential gain.

\section{INTRODUCTION}

The rapid development of unconventional tight oil ${ }^{1}$ resources (commonly referred to as "shale oil") in the USA has had a significant impact on the pricing and availability of global oil supplies. The abundance of the resource surprised many in the petroleum industry (Sanderson et al., 2019), and it has once again turned the USA into an energy powerhouse. Plentiful shale oil arguably provided the impetus for repealing the 1975 oil export ban in December 2015, and in October 2019 the USA be-

\footnotetext{
${ }^{1}$ Hitachi Energy, Zurich, Switzerland.

${ }^{2}$ Rivier University, Nashua, NH, USA.

${ }^{3}$ Economic Insight, Portland, OR, USA.

${ }^{4}$ Colorado State University, Fort Collins, CO, USA.

${ }^{5}$ To whom correspondence should be addressed; e-mail: marc. vatter@hitachienergy.com, mvatter@rivier.edu

${ }^{1}$ Light crude oil trapped in low-permeability rocks, sometimes referred to as "light tight oil" (LTO). See Zhang et al. (2016a, 2016b) for more details.
}

came a net oil exporter, however briefly (EIA, n.d.a). The country's newfound source of oil supply may have been responsible, at least in part, for a global oil price decline experienced after 2014.

The development of shale oil resources in the last decade has raised a series of interesting questions centered on the long-term viability of shale oil production, including the following:

- Rapidly falling oil prices in 2015 and 2016 caused drilling and well completion to drop precipitously; and yet, surprisingly, production held firm during this timeframe, despite the faster rate of production decline in shale oil wells compared to conventional oil wells. How can this be explained?

- As a "marginal resource," how important has shale oil become in balancing global oil demand and supply?

- The decline in price, attributed to the shale boom by observers like Hanewald (2017), 
prompted them to declare the OPEC cartel moribund. How much, in fact, has the shale boom reduced OPEC's market power?

- In the short- and medium-term, marginal costs for North American shale plays exceed those for conventional oil in the Persian Gulf. How vulnerable are shale oil producers to volatile pricing and supply decisions by OPEC $+?^{2}$

- Although production in shale oil wells declines rapidly in the first few months, it also has a "long tail." The vast majority of shale oil wells continue to produce at some level for many years. How will this impact the future oil market?

- Any natural resource has an earth-bound limit, and yet shale oil exhibits characteristics of unboundedness. Will "peak oil" again emerge as a concern, and if so, when (Ngai et al., 2019)? Put another way, is shale oil a passing fad or a permanent reset of the oil market?

While we do not pretend to have full and complete answers to all of these questions, we present an in-depth review of sample data pertaining to the Bakken Shale oil play in North Dakota, one of the major shale provinces in the USA. Our research provides some insight into the productivity and price sensitivity of well development within the state and, by inference, the resource in general.

\section{Background Information}

The "Bakken Shale" is a term commonly used to identify an expansive rock formation that lies beneath Northeastern Montana, Western North Dakota, and Northwestern South Dakota, as well as Southeastern Saskatchewan and Southwestern Manitoba (Fig. 1). Historically, the region has been known as the "Williston Basin." The Bakken Shale is a world-class, layered petroleum system spanning three different strata or formations (listed in ascending order): the Devonian Three Forks Formation; the Upper Devonian to Lower Mississippian Bakken Formation; and the lower part of the Mississippian Lodgepole Formation (Gaswirth et al.,

\footnotetext{
${ }^{2}$ OPEC+ is an alliance of OPEC and non-OPEC countries that has been pursuing supply "corrections" in the oil market since 2017.
}

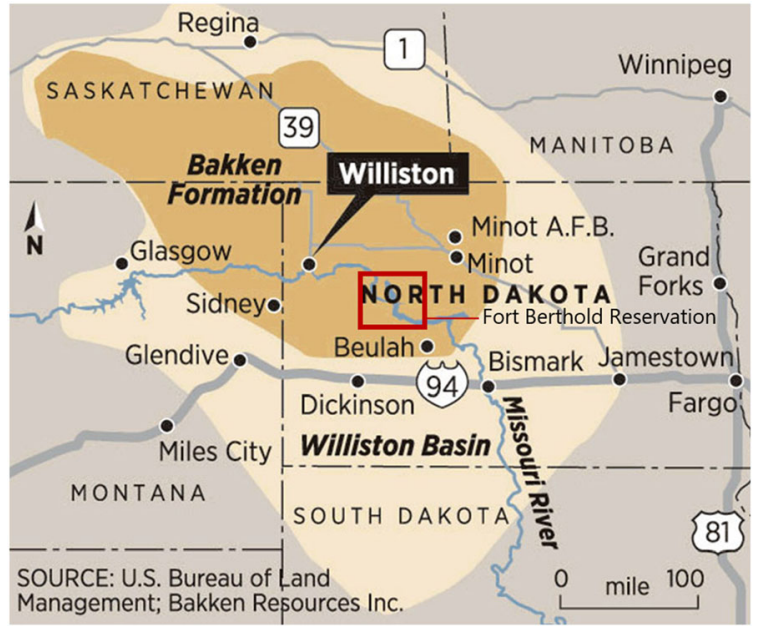

Figure 1. Map illustrating the approximate extent of the Williston Basin (beige) and the Bakken Formation (tan). Originally published by the Spokane Spokesman-Review and reproduced with permission. The approximate boundaries of the Fort Berthold Reservation are added.

2013; Gaswirth \& Marra, 2015). The Bakken Formation consists of four distinguishable members or subunits, again listed from deepest to shallowest: Pronghorn Member (sometimes called the "Sanish Sand"); Lower Bakken Shale; Middle Bakken Member (which is silty and dolomitic); and Upper Bakken Shale (Theloy \& Sonnenberg, 2013). The Upper Bakken Shale is the most geographically expansive of the four units, and the Pronghorn Member is the least. The Pronghorn has been found to be in fluid communication with the underlying Three Forks formation (and is sometimes regarded as part of that formation), which is similarly divided into upper and lower members (Gaswirth et al., 2013). The Middle Bakken, Lower Lodgepole, and Upper Three Forks comprise the primary reservoirs (NETL, 2011), with the upper and lower shale members being the main source rocks (Gaswirth et al., 2013). These various formations are commonly lumped together as the "Bakken Shale." The Bakken Shale is largely a technology-driven play (Theloy \& Sonnenberg, 2013), with progressive advances in horizontal drilling and hydraulic fracturing, along with other factors, thought to be principally responsible for wells with greater initial productivity being drilled over time.

Production from the Bakken Shale is centered in North Dakota (in the area of the Fort Berthold Reservation) where the Middle Bakken and Three Forks formations represent the thickest part of the basin. Annual oil production in North Dakota in- 
creased from 123 thousand barrels ${ }^{3}$ per day in 2007 to 1.5 million barrels per day at the end of 2019 (North Dakota State Industrial Commission [NDIC], n.d.a), over a ten-fold increase. The state provides publicly available data on the number and types of oil wells, producers/operators, well locations, monthly production, and other pertinent information (NDIC, n.d.b). As of 2019, North Dakota listed 17,220 producing oil wells, $97 \%$ of which were horizontal hydraulically fractured wells (NDIC, n.d.c). The modeling effort described in this paper focuses on 4360 such wells that were completed between March 2015 and May 2019 in the Middle Bakken and Three Forks members of the Bakken Formation.

Participation by industry players in development of the Bakken Shale has been remarkably diverse. In our sample data set, there were 40 producers, the vast majority of which were small, independent oil companies. Over time, Continental Resources has been the largest company operating in the basin, but it produced only $11.4 \%$ of the crude oil considered here.

Infrastructure shortages have persistently plagued the Williston Basin region. Until recently, pipeline takeaway capacity out of the region was limited, leaving much of the interstate transportation to more costly rail. ${ }^{4}$ In addition, because monthly well production varies widely, traditional gathering pipelines can be somewhat impractical and uneconomic to construct, and movement of crude oil away from individual wells is often relegated to trucking.

The diverse and constrained infrastructure situation has had an impact on pricing, in addition to production operations. During periods of rapid growth (2012-2014), North Dakota "first purchase" oil prices trailed West Texas Intermediate (WTI) prices by as much as $\$ 20$ per barrel (EIA, n.d.a), or $19 \%$, even as WTI itself was discounted against the price of Brent crude oil by $15 \%$ in the international market. In 2018 and 2019, the discount below WTI averaged $\$ 4.34$ per barrel (EIA, n.d.a), or $7 \%$. Generally, the high cost of moving Bakken oil to market explains the differential, but companies with

\footnotetext{
${ }^{3}$ There are nearly $159 \mathrm{~L}$ in a barrel of crude oil. We abbreviate "barrels" "bbl".

${ }^{4}$ Start-up of the Dakota Access Pipeline (DAPL) in mid-2017 provided much needed takeaway capacity, but protests and judicial review have put its continued operation at risk.
}

hedged risk to congestion on interstate pipelines may obtain a much higher netback.

\section{Description of Sample Data}

Table 1 provides an overview of horizontal wells in North Dakota and the sample we extracted to analyze changing well productivity. Our sample was drawn in two steps. First, North Dakota's horizontal well data were extracted from NDIC's webpage (NDIC, n.d.b), which identifies six producing zones-Middle Bakken, Three Forks, Middle Bakken/Three Forks, Lodgepole, Upper Bakken Shale, and Lodgepole/Middle Bakken. ${ }^{5}$ In our sample period, however, only the first three were relevant. Next, well production data for each month from May 2015 to May 2019 were merged with the set of North Dakota's horizontal wells completed beginning March 2015 (NDIC, n.d.c). This action reduced the number of wells to be analyzed by about twothirds.

Table 1 summarizes historical completion and production activity in the Bakken Shale within North Dakota. Note that wells completed in 2015 averaged 1926 barrels per month in May 2019. In contrast, wells completed in the first 5 months of 2019 averaged 21,643 barrels per month in May 2019. This increase is a combination of natural decline over 4 years for the wells completed in 2015, productivity increases, and the randomness of the data. Our econometric analysis quantifies these effects separately.

\section{Response to a Drop in Oil Prices}

Until recently, oil prices remained on the low side after 2013 (and troughed in early 2020). Lower prices had a direct impact on drilling and the number of wells completed, even though there is a time lag between drilling and well completion. According to the NDIC, new horizontal wells in the Bakken Formation declined from 2273 in 2014 to 738 in

\footnotetext{
${ }^{5}$ Note that these producing zones represent somewhat different groupings than those described under "Background information" and portrayed in the stratigraphic column published by the North Dakota Geological Survey (Bader et al., 2018).
} 
Table 1. Historical completion and production activity in the Bakken Formation within North Dakota

\begin{tabular}{|c|c|c|c|c|c|c|}
\hline Year & Completions & $\begin{array}{l}\text { Annual } \\
\text { production } \\
(\mathrm{bbl})^{\mathrm{a}}\end{array}$ & $\begin{array}{l}\text { Number of then-com- } \\
\text { pleted wells remaining } \\
\text { active }\end{array}$ & $\begin{array}{c}\text { Sample average num- } \\
\text { ber of monthly com- } \\
\text { pletions }{ }^{\mathrm{b}}\end{array}$ & $\begin{array}{l}\text { Sample average production of } \\
\text { then-completed wells in May } \\
\text { of } 2019^{\mathrm{a}}\end{array}$ & $\begin{array}{l}\text { North Dakota first } \\
\text { purchase price }(\$ / \\
\text { bbl) }\end{array}$ \\
\hline Prior & 299 & $29,673,715$ & 298 & & & \\
\hline 1986 & 1 & 45,659 & 1 & & & 13.54 \\
\hline 1987 & 1 & 372,076 & 1 & & & 16.76 \\
\hline 1988 & 10 & 974,059 & 4 & & & 13.85 \\
\hline 1989 & 30 & $4,354,147$ & 20 & & & 17.12 \\
\hline 1990 & 70 & $6,828,218$ & 18 & & & 21.94 \\
\hline 1991 & 44 & $4,511,277$ & 12 & & & 18.80 \\
\hline 1992 & 31 & $4,362,810$ & 18 & & & 18.02 \\
\hline 1993 & 24 & $2,217,021$ & 13 & & & 15.42 \\
\hline 1994 & 10 & 980,890 & 6 & & & 14.08 \\
\hline 1995 & 2 & 85,294 & 1 & & & 15.58 \\
\hline 1996 & - & - & - & & & 19.46 \\
\hline 1997 & 1 & 4019 & 1 & & & 17.63 \\
\hline 1998 & - & - & - & & & 11.39 \\
\hline 1999 & - & - & - & & & 16.70 \\
\hline 2000 & - & - & - & & & 28.19 \\
\hline 2001 & 2 & 124,938 & 2 & & & 23.55 \\
\hline 2002 & - & - & - & & & 24.15 \\
\hline 2003 & 1 & 2184 & 1 & & & 29.27 \\
\hline 2004 & 6 & 613,951 & 5 & & & 39.30 \\
\hline 2005 & 32 & $3,476,817$ & 23 & & & 52.38 \\
\hline 2006 & 75 & $11,799,659$ & 66 & & & 56.69 \\
\hline 2007 & 165 & $37,775,698$ & 158 & & & 65.30 \\
\hline 2008 & 435 & $134,435,540$ & 423 & & & 88.68 \\
\hline 2009 & 477 & $130,602,519$ & 472 & & & 53.75 \\
\hline 2010 & 771 & $207,119,902$ & 762 & & & 70.26 \\
\hline 2011 & 1,239 & $319,460,437$ & 1228 & & & 88.74 \\
\hline 2012 & 1,795 & $408,893,608$ & 1778 & & & 84.06 \\
\hline 2013 & 1,984 & $456,101,219$ & 1977 & & & 90.22 \\
\hline 2014 & 2,155 & $472,983,119$ & 2152 & & & 82.89 \\
\hline 2015 & 1,489 & $335,012,276$ & 1458 & 102 & 1926 & 41.42 \\
\hline 2016 & 726 & $175,502,321$ & 726 & 48 & 2574 & 36.51 \\
\hline 2017 & 972 & $255,025,347$ & 972 & 66 & 4530 & 47.04 \\
\hline 2018 & 1,221 & $300,634,376$ & 1221 & 82 & 11,445 & 60.27 \\
\hline 2019 & 1,085 & $205,028,781$ & 1085 & 43 & 21,643 & 52.60 \\
\hline
\end{tabular}

Sample included wells from the Middle Bakken and Three Forks members

a"bbl" stands for "barrels," which each contain nearly $159 \mathrm{~L}$ of crude oil

bSample includes wells completed between March 2015 and May 2019, inclusive

Source: North Dakota Industrial Commission, Department of Mineral Resources, Oil and Gas Division (NDIC, n.d.c)

2016, a drop pf $68 \% .^{6}$ Figure 2 illustrates the relationship between oil prices and the number of North Dakota horizontal wells completed from 2005 to 2019. Additionally, Figure 2 includes an index of annual oil production. For comparability, well completion and production data are presented as indexes, with those for 2018 equal to 100.

It is evident in Figure 2 that the precipitous drop in well completions tracked the collapse of the

\footnotetext{
${ }^{6}$ These totals include wells and production in addition to those tabulated in Table 1 due to unclassified data and drilling in formations other than those covered in Table 1.
}

oil price in 2014, but production did not. Although the state's horizontal well completions fell $68 \%$ between 2014 and 2016, oil production from horizontal wells fell only $4 \%$. The industry was rocked again in 2020 following the swift drop in oil prices due to Covid-19, and this time production did not snap back. North Dakota's July 2020 production was 30\% lower than in December 2019. Perhaps more significantly, as of July 2020, only two North Dakota horizontal wells from the Bakken had been completed since 2019 . 


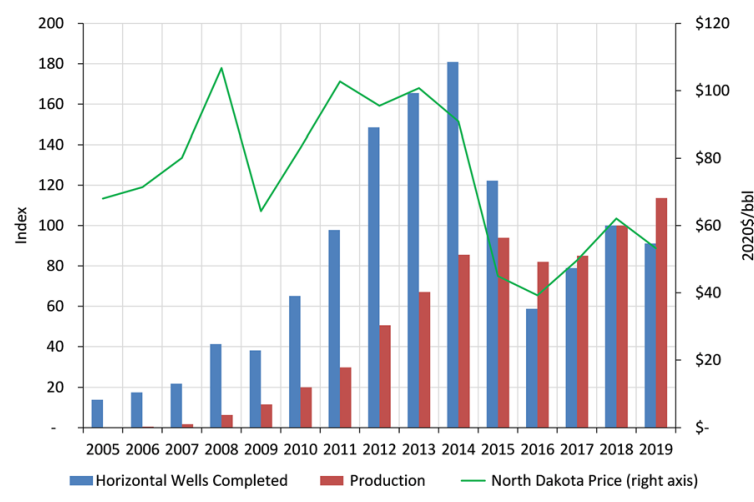

Figure 2. Horizontal wells completed in North Dakota compared to Bakken oil production and first purchase price; $1 \mathrm{bbl} \approx 159 \mathrm{~L}$; sources are EIA (n.d.b.), NDIC (n.d.a.), and FRED (n.d.).

\section{Technological Gain}

The most extraordinary feature of the 4-year period was a significant increase in well productivity. Without controlling for other variables, production from March 2019 well completions was initially almost four times higher than from wells completed in March 2015. This reflects what we interpret to be a "technological gain" (sometimes referred to as an "experiential gain") in productivity. (Our econometric modeling of oil supply in the North Dakota Bakken Shale suggests that, over 49 months, productivity nearly doubled, rather than quadrupling, but that analysis controls for location, prices of oil and oil and gas equity, and other factors.) Various drilling, completion, and operating improvements achieved in recent years have all contributed to this technological shift or enhancement, including overall improved knowledge of the resource, a longer drilling range, better fracking techniques, improved chemicals and drilling fluids, and the like. Additionally, until the Covid-19 crisis in 2020, small oil companies still had reasonable access to financing.

Over time, the development of shale oil has sometimes proceeded by trial and error (at least, in the early stages), with successes quickly mimicked and failures left behind. In this respect, technological progress is similar to that of other industries. As noted by Killefer (1948), "Inventions do not spring up perfect and ready for use ... One seldom knows who the real father is. The period of gestation is long with many false pains and strange forebirths."

The idea of technological gain associated with drilling and development of unconventional oil and gas wells is of considerable interest and has been addressed elsewhere in the petroleum literature (Covert, 2015; Fitzgerald, 2015; Montgomery \& O'Sullivan, 2017). However, to date, no definitive metric or indicator has been established. For purposes of the present study, we use a simple function of time to account for technological progress, since time can encompass many individual and often unidentified contributors. For example, it can serve as a proxy for changes in the mix of fracking fluids, flexible pipelines that can be reused, and a variety of other innovations that are particularly well-suited for shale oil development. Assuming the other variables in a model represent the factors of production well, a time-trend as a proxy for technological change is similar to the "Solow (1956) residual," which measures technological progress in his classic model of economic growth. ${ }^{7}$

Further, in some cases, new technologies may have a limited impact by themselves, but may lead to unanticipated synergies over time when combined with other innovations. Indeed, in the case of shale oil development, the combination of two technologies-horizontal drilling and hydraulic fracturing-has resulted in much greater productivity than likely could have been attributed to both technologies used separately (EIA, 2018).

In the Bakken Shale, technological gain is also confounded with attempts by operators to accommodate the naturally occurring variation in geology, petrophysics, and reservoir response. Several authors (Denney, 2011; Pilcher et al., 2011; LaFollette, 2013; Sanderson et al., 2019; Attanasi \& Freeman, 2020; Attanasi et al., 2020a, 2020b) address the physical drivers of well productivity in shale oil plays.

We also note in passing that oil and natural gas are produced in conjunction with each other (production complements), and that progressive increases in the productivity of natural gas plays, including the Bakken (EIA, 2020), have also been observed.

\section{Long Tail of Production}

The rapid decline in production from a horizontal hydraulically fractured shale oil well does not continue indefinitely, and, as in the case of conven-

\footnotetext{
${ }^{7}$ See Kenton (2021) for an accessible discussion.
} 
tional wells, horizontal Bakken Shale oil wells can have substantial longevity. ${ }^{8}$ Further, only a few years after completion, they also have relatively lower production rates than most conventional wells. Among other factors, the change in flow rate is the consequence of the natural progression of a horizontal shale well's production from transient flow to boundary-dominated flow (or some other flow regime), as described in, among others, Kabir et al. (2011), Zhou et al. (2017), Zhang et al., (2016a, 2016b), Luo et al. (2018), Yang et al. (2019) and Attanasi et al. (2019). The full history of horizontal wells drilled in the Bakken Shale and summarized in Table 1 demonstrates this revealing characteristic. As the table illustrates, the decade from 1986 to 1995 appears to have been primarily a period of experimentation. By the end of the period, horizontal wells were only $8.6 \%$ of North Dakota's total production. Low oil prices effectively ended the experiment until 2004.

Figure 3 compares average monthly production from all horizontal wells in the Bakken and Three Forks formations completed in March 2015, 2016, 2017, and 2018. (Insufficient observations, ending in May, would make wells completed in March 2019 uninteresting.) The chart illustrates the initial rapid decline followed by the long tail of production. Although the figure demonstrates the steep decline rate, there remains a great deal of randomness, even on average. Note that the early months of production in 2016 showed considerable improvement compared to 2015, but average levels converged after the sixth month of production. In contrast, there appeared to be improvement in every month in 2017 and 2018 (average rates in later months were not yet available).

\section{Shale Oil as a Balance Wheel}

Easy to find conventional oil fields have long since disappeared in North America. As the industry turned to offshore and more difficult environments, lead times increased. For example, Prudhoe Bay was discovered in 1968 , but the oil did not come to market until 1977, following the completion of the

\footnotetext{
${ }^{8}$ The length of life for both conventional and horizontal, hydraulically fractured shale wells depends on a number of factors, including geology, initial completion practices, restimulation and related well management activities, and economics, although the interaction of all such factors may differ for the two categories.
}

Alyeska Pipeline. In the early decades of the American industry, rapid conventional oil production expansion in the USA led to pro-rationing, but economic theory tells us that the first opportunities exploited in producing a good will be the easiest. Prudhoe Bay was lower on the list in terms of ease of exploration, development, production, and transportation, and the fact that it was exploited decades ago underscores the point that the easy opportunities for conventional production in North America are gone. Currently, at least, the time needed to develop shale oil resources is much shorter.

Moreover, production flow from conventional wells can last for decades, while, as noted previously, production from tight oil wells declines rapidly in the first few months-more rapidly than at conventional wells. North Slope oil production peaked in 1989, over a decade after production began, and has declined at a slow rate since then. Nearly half of a horizontal, hydraulically fractured shale well's total production will be produced in the first 12 months. In this sense, shale oil development and drilling are more like a standard manufacturing process that can be explained by the Marshallian partial equilibrium model of a firm (Newell et al., 2016; Mandy, 2017). In this competitive model, flexible production, along with rapid entry and exit, makes long-term prices more predictable. Previously, prices have peaked in periods of excess demand, or disruption of supply, and then fallen back for decades. Prices still fluctuate, but, in the presence of tight oil, the variations have been smaller since 2014 than they have been since the turn of the century, and smaller than during the 1970s and early 1980s (Fig. 4).

Given the long lead times and massive capital investment needed to develop most conventional oil fields, prices match long-term marginal costs only by accident. In contrast, shale oil's lead time is typically 1-3 years, making it much more responsive to changing prices, and keeping long-run marginal cost closer to price.

The Organization of Petroleum Exporting Countries (OPEC) depends on a swing producer or producers to optimize prices. Given pressure from other oil exporters, however, the cartel's largest producer, Saudi Arabia, has found this role increasingly difficult and resists going it alone. In most circumstances, the margin of oil supply that balances the market is thought to be small, on the order of three to five million barrels per day or less, out of global demand in 2019 of just over 100 million barrels per day. (The massive oil demand drop due 


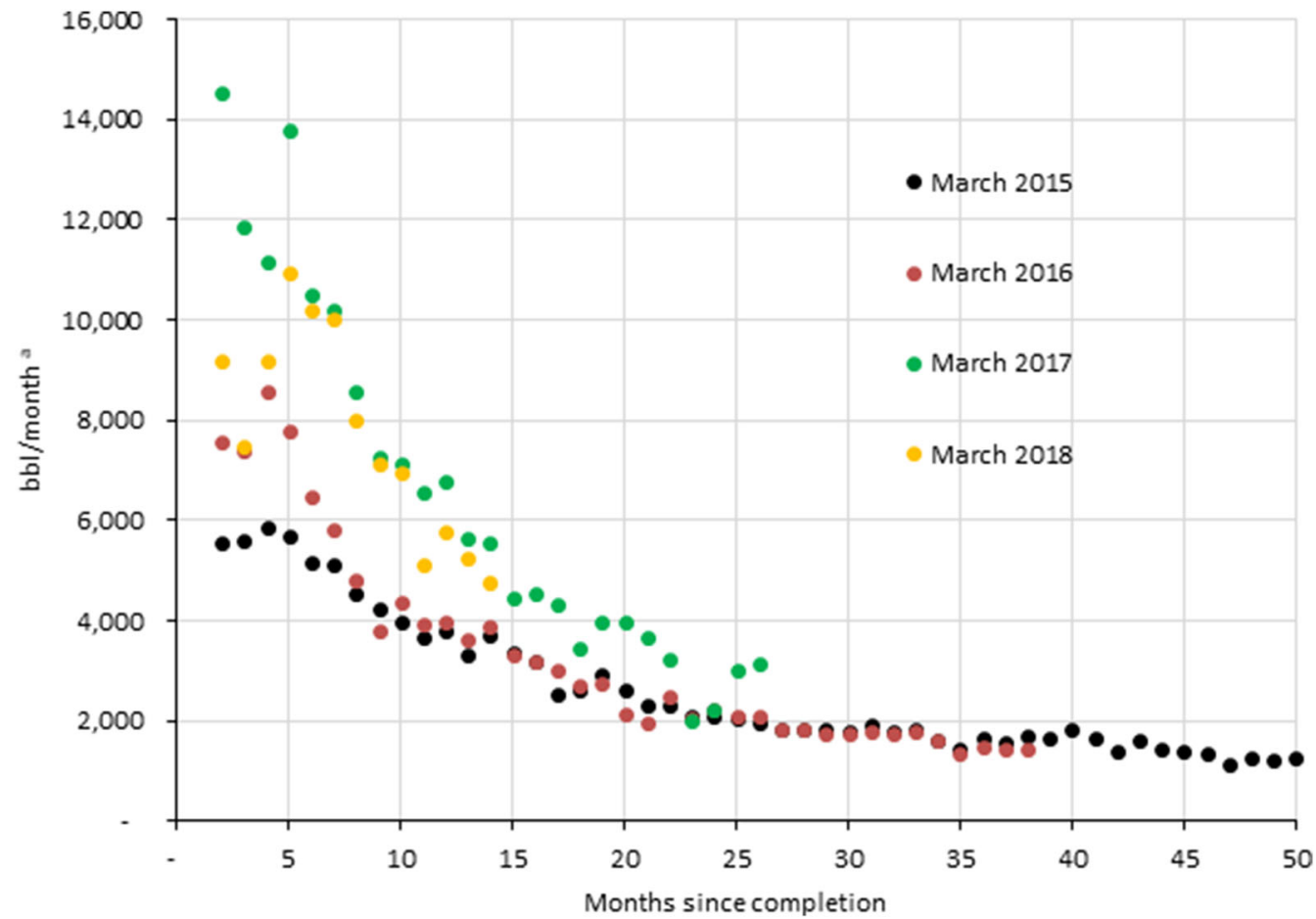

Figure 3. Monthly average production from wells completed in March 2015, 2016, 2017, and 2018. "“bbl" stands for "barrels," each of which contains nearly $159 \mathrm{~L}$ of crude oil.

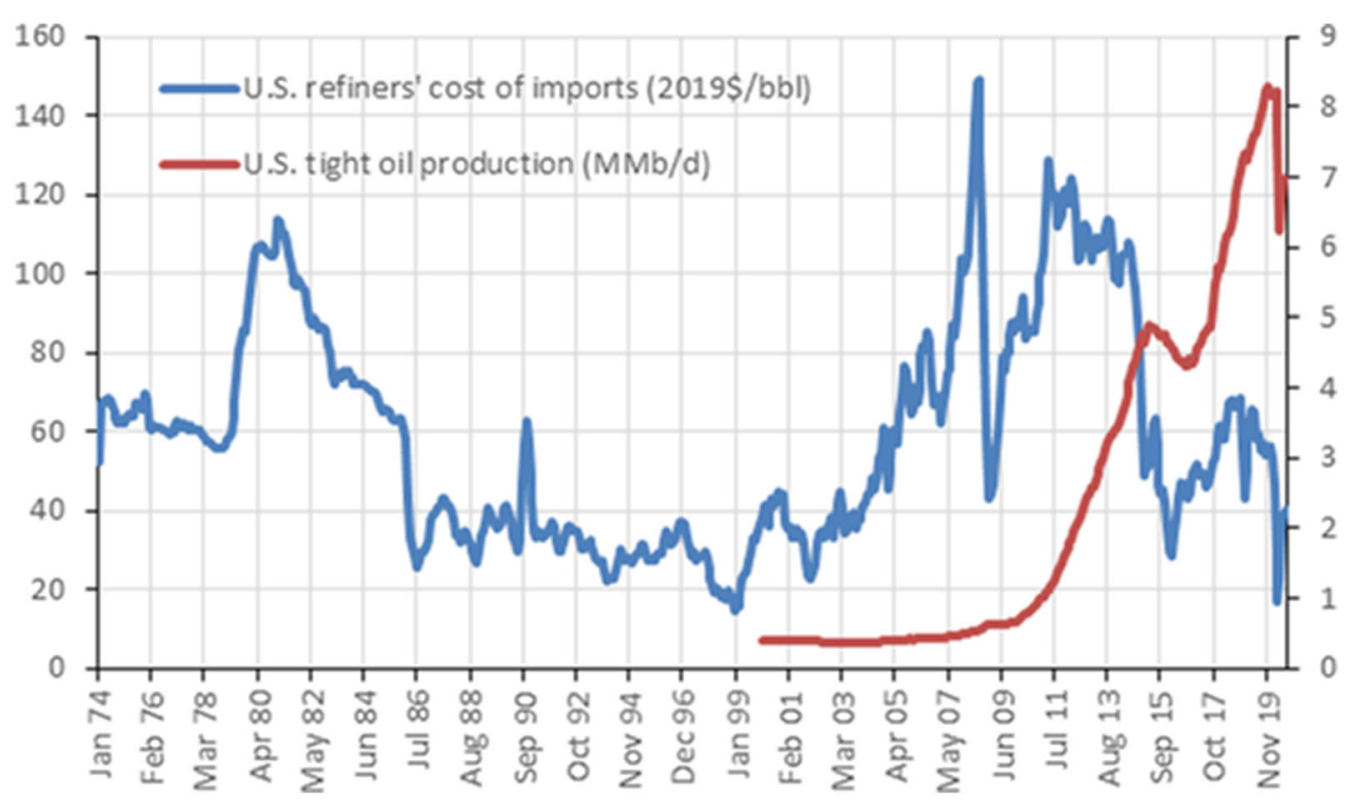

Figure 4. Monthly average world price and US tight oil production. "bbl" stands for "barrels," each of which contains nearly $159 \mathrm{~L}$ of crude oil; "MMb/d" stands for "million barrels per day." Source: EIA (2020) and EIA (n.d.c). 
to Covid-19 obviously shifted this equation.) In contrast, tight oil production in the USA alone reached 8.2 million barrels per day in early 2020 and in a normal year would have continued as the margin of production. If drilling and well development were to completely stop, this figure could drop by half in a little over a year. Likewise, given adequate incentives, production could ramp up quickly. For example, total North Dakota oil production, the majority of which comes from tight oil resources, increased by $18 \%$ in 2018 and $12 \%$ in 2019 in the face of relatively modest oil prices.

The ability of shale oil to impact markets can be measured by its price elasticity. Based on our econometric modeling of oil supply in the North Dakota Bakken Shale, along with comparisons to prior work, we conclude that the short-run supply price elasticity of shale oil is higher than that of other non-OPEC sources, and that the resource can, indeed, act as a balance wheel.

\section{ECONOMETRIC MODELING OF OIL SUPPLY IN THE NORTH DAKOTA BAKKEN SHALE}

\section{Sample Data}

Table 2 describes the sample database on which the econometric analysis was performed. In total, we analyzed 4360 wells completed between March 2015 and May 2019 in the Bakken and Three Forks formations. Production from the wells averaged 3442 barrels per month, but the standard deviation was twice that level-reflecting the data's volatility. We excluded observations of positive production below 100 barrels, as those data largely appeared to be erroneous. Since the number of new wells dropped off in 2016 and 2017 before rising in 2018, the average time in production was just under 10 months, and slightly less from the month of peak production. Average well production in the peak month was 19,710 , again with a huge range, from 1 to 139,068 barrels per month. On average, there were two wells drilled in each quarter-quarter section (Public Land Use Survey System [PLSS], USGS (n.d.)), but one quarter-quarter section had 21 wells. North Dakota's first purchase price averaged around $\$ 49$ per barrel, but had a low of \$24 and a high of $\$ 68$, again reflecting the volatile market, and giving us rich variation without outliers for the estimation of price elasticity. Likewise, the value of the Stan- dard \& Poor's Oil \& Gas Exploration and Production Energy Trading Fund, which we used to measure access to capital, fluctuated widely, from a low of $\$ 25.17$ to a high of $\$ 52.43$. As noted, much of the drilling was located in or near the Fort Berthold Reservation (Fig. 1).

\section{General Modeling Approach}

We used a panel approach (Diggle et al., 2002; Hsiao, 2003; Frees, 2004; Baltagi, 2008) to estimate physical and economic relationships among the data, where the cross-sectional unit was the well, of which there were 4360, and the temporal unit was the month, of which there were 49. For this wide-short panel arrangement, we followed the recommendations of Kennedy (2008), employing pooled ordinary least squares (OLS), fixed effects, or random effects estimation for "a wide, short panel, in which $N$, the number of cross-sectional units, is large, and $T$, the number of time periods, is small." The methodology proceeds by testing the null hypothesis, $\mathrm{H}_{0}$, of equal intercepts for all cross-sectional units, and pooling the data if the hypothesis is not rejected (Kennedy, 2008). A Hausman test (Hausman, 1978; Torres-Reyna, 2007) is then normally used to compare fixed and random effects, where the latter is unbiased only if the regressors are independent of the random effects, but fixed effects cannot be estimated when any of the regressors are time-invariant, and we use several transformations of latitude and longitude as regressors.

Using this general approach, we developed two different equations, or modeling scenarios. In the first case (Model 1), we assumed continuous production; i.e., months of no production are omitted. In this case, we rejected $\mathrm{H}_{0}$ and concluded intercepts are not equal. We took the random effects estimator to be unbiased because we could not perform the Hausman test against fixed effects with the time-invariant regressors.

In the second case (Model 2), we allowed gaps in production for either technical or economic reasons, and count months prior to completion as observations of zero production (to account for the impact of regressors such as price on the timing of completion). In this case, we did not reject $\mathrm{H}_{0}$, which led us to pool the data (Kennedy, 2008). Note that random effects were also considered proxies for omitted variables (regressors), and finding them to be superfluous suggests that Model 2 was well specified. 
Table 2. Summary of sample data by well and month; May 2015-May 2019

\begin{tabular}{|c|c|c|c|c|}
\hline Variable & Mean & SD & Min & Max \\
\hline Production $(\mathrm{bbl})^{\mathrm{a}}$ & 3442 & 6348 & 0 & 139,068 \\
\hline Months in production & 9.58 & 12.93 & 0 & 50 \\
\hline Months following peak & 8.01 & 11.72 & 0 & 49 \\
\hline Production at peak & 19,710 & 14,049 & 1 & 139,068 \\
\hline Co-located wells & 2.14 & 2.51 & 0 & 21 \\
\hline ND first purchase price $(\$ / b b l)$ & 48.83 & 10.59 & 24.12 & 67.77 \\
\hline S\&P O\&G Energy Trading Fund price ${ }^{\mathrm{b}}$ & 36.65 & 5.53 & 25.17 & 52.43 \\
\hline Latitude & 47.95 & 0.32 & 46.89 & 49 \\
\hline Longitude & -102.99 & 0.39 & -103.99 & -102.12 \\
\hline
\end{tabular}

Sources: EIA (2020); NASDAQ (n.d.); North Dakota Industrial Commission, Department of Mineral Resources, Oil and Gas Division (n.d.a-c). S\&P O\&G = Standard \& Poor's Oil \& Gas

a "bbl" stands for "barrels," each of which contains nearly $159 \mathrm{~L}$ of crude oil

b January 2019 USD, adjusted using the Consumer Price Index for All Urban Consumers

\section{Model 1: Continuous Production}

"Continuous production" is defined here as uninterrupted flow and excludes breaks or pauses in production encompassing an entire month, as well as all other occurrences that can be regarded as zero production. This means that we discarded observations of zero production for an entire month, both before and after a well is completed, from our sample. (Such observations are restored and discussed in the description of Model 2: Discontinuous Production.) Partial months of production were included in the sample. This simplified the task of estimating the rate at which production declines over the life of a well.

\section{Estimation of Model 1}

Using the data summarized in Table 2, and excluding observations of zero production, we used the software Stata ${ }^{\circledR}$ (StataCorp, n.d.) to estimate an equation with a different randomly distributed intercept for each well, having rejected a null hypothesis that the intercept is the same for each well, and being unable to use a fixed well effect because the transformations of latitude and longitude that we include as regressors do not vary over time. The random effects reduced any omitted variable bias. For example, wells may differ in terms of the number and durations of shut-ins.

\section{Results for Model 1}

The following equation was estimated:

$$
\begin{aligned}
& q_{i t}=\underset{4.7054}{53.7654}-\underset{0.0003}{0.0037} M_{i t}-\underset{0.0046}{0.4472} m_{i t}+\underset{0.0052}{0.2555} q_{i t-1} \\
& -\underset{0.0018}{0.0165} W_{i t-1}+\underset{0.0003}{0.0090} I_{i}-0.0211 e^{L a t_{i}} \\
& -\underset{19.2171}{173.4584} e^{\text {Long }_{i}}-\underset{0.4644}{2.7164 \text { Lat }_{i}-13.9810 \text { Long }_{i}}
\end{aligned}
$$

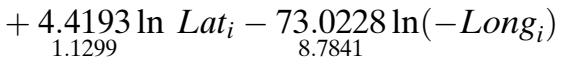

$$
\begin{aligned}
& -\underset{0.0444}{0.4665 \text { Lat }_{i}} \cdot \text { Long }_{i}+\underset{0.0179}{0.0598 d p_{t}}+\underset{0.0173}{0.1847 d p_{t-3}} \\
& +0.0006 F_{t-1}
\end{aligned}
$$

where $q_{i t}$ is $\log$ production at well $i$ in month $t$ in bbl, ${ }^{9} M_{i t}$ is months in production starting with peak at well $i$ in month $t, m_{i t}$ is the natural $\log$ of $M_{i t}, W_{i t}$ is the number of producing wells in the PLSS quarterquarter section at well $i$ as of month $t, I_{i}$ is initial month of production at well $i$, Long $_{i}$ is longitude of well $i,+100^{\circ}, L_{a t}$ is latitude of well $i,-45^{\circ}, d p_{t}$ is the first difference in log North Dakota first purchase in month $t$ in $\$ / b b l$, adjusted for inflation using the Consumer Price Index for All Urban Consumers, and $F_{t}$ is the share price of Standard \& Poor's Oil \& Gas Energy Trading Fund in month $t$, also adjusted for inflation using the Consumer Price Index for All Urban Consumers.

The logarithm of production was used as the dependent variable, so predicted production can never be negative. Both levels and logarithms of months in production since peak had negative coefficients, and the functional flexibility afforded by including both transformations of the variable al-

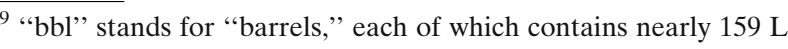
of crude oil.
} 
lowed for the characteristic rapid initial decline rates of shale wells.

Standard errors are shown below the coefficients. Inference is robust to heteroscedasticity and autocorrelation. That is, in calculating the standard errors, the (Huber-White) error term is not restricted to be spherical (Freeman, 2006).

All of the coefficients in Model 1 were statistically significant at the 0.05 level or better. The overall $R^{2}$ was 0.66 . $\rho$, the fraction of the variance in $q_{i t}$ explained by the random effects, was 0.18 . The full Stata header is shown in Table 8 in the appendix. The estimated persistence in production, $q_{i t-1}=0.2555$, suggests that operators had flexibility to vary production from 1 month to the next, but that some such changes would be difficult or impose a cost. Since the sample omits gaps in production, the coefficient on $q_{i t-1}$ does not reflect the cost of shutting in or restarting a well.

The coefficient on initial month of production, $I_{i}$, was positive, which we interpreted as reflecting technological progress. This is noteworthy because, by specifying initial month in levels and production in logs, the impact of technological progress is shown to be greatest when wells are at their most productive; i.e., early in their lives. Nonetheless, technological progress has the potential to impact production throughout the life of a well. As Kah (2018) has noted, "While improvement from any specific activity may come to an end, there should still be a long way to go in overall technological advancement." Fitzgerald (2015) also found evidence of learning in hydraulic fracturing using data from the Bakken Shale.

Economists, like Solow (1956), define "technological progress" as an increase in the ratio of production to (a weighted average of) the factors of production used, a.k.a. "total factor productivity." This technological progress must be identified separately from the effects of changes in the use of factors when total factor productivity does not change; per well, the volume of injected fluids, proppant, and the number of fracture treatments changed within the sample period. Equation 1 sorts this out. A small, profit-maximizing producer will only increase the use of a factor of production (e.g., proppant) if (1) the price of the product (here, crude oil) rises, (2) the price of proppant falls, (3) the price of another factor (e.g., well length) changes, or (4) she learns how to produce more crude oil with no change in total cost, or in the price of any factor of production. If the prices of crude oil and its factors of production are held constant, then one can rule out Cases 1-3, and Case 4 is what we call "technological progress." Including a variable in a regression is a way to hold its value constant while the others change. Case 1 is modeled in Eq. 1 in the price terms, and Case 4 in the term for initial month of production, $I_{i}$, whose coefficient, our estimate of technological progress, could be biased if we did not somehow model Cases 2 and 3. In the parlance of econometrics, this would be referred to as "omitted variable bias."

Here is how we model Cases 2 and 3: Data on prices or quantities of materials and labor employed in the Bakken Shale are not publicly available, but these omitted variables correlate with the prices of oil included in Eq. 1, and with oil and gas equity, represented by $F_{t-1}$ in Eq. 1 . The price of equity is the value of present and expected future profits; $F_{0}=\sum_{t=0}^{\infty}\left(P_{t}^{\text {Ind }} Q_{t}^{\text {Ind }}-\vec{W}_{t}^{\text {Ind }} \vec{\theta}_{t}^{\text {Ind }}\right)(1+r)^{-t}, \quad$ where $P_{t}^{\text {Ind }}$ is the price of crude oil at Time $t, Q_{t}^{\text {Ind }}$ is crude oil produced, $\vec{W}_{t}^{\text {Ind }}$ is a vector of factor prices, $\vec{\theta}_{t}^{\text {Ind }}$ is a corresponding vector of factors employed to produce $Q_{t}^{\text {Ind }}$, the "Ind" superscripts indicate that the variables are industry-wide, and $r$ is the temporal discount rate. An increase in any $W_{0}^{\text {Ind }}$ will directly lower $F_{0}$, and likely indirectly lower it by influencing expectations for $t>0 . \vec{\theta}_{t}$ weights the prices of intensively used inputs relatively heavily, and so they effectively have larger coefficients in Eq. 1. Financial markets are very sensitive to changes in the costs of companies who issue financial instruments, so we have meaningfully controlled for the prices of factors of production used throughout the industry in Eq. 1.

Indeed, fracking fluids (Alibaba, n.d.) and proppant (Market Watch, 2021) are traded globally, so changes in their prices in the Bakken correlate with changes worldwide and, therefore, with the price of globally traded oil and gas equity. There is also a geographically mobile pool of oil field labor that causes wages in the Bakken to correlate with those elsewhere in the industry and, therefore, also with the price of equity. Inasmuch as greater use of fluid, proppant, or labor represents a movement along the supply curve (Case 1), we modeled that by making production, $q_{i t}$, a function of the price of oil, $p_{t}$; inasmuch as it represents a shift in the industry supply curve (Cases 2 and 3), we have modeled that by making production a function of the price of equity, $F_{t-1}$. 
As to the supply curve for the firm, the random effects, which allow for a different intercept term at each well, can also stand in for omitted prices or quantities of variable factors of production (Cases 2 and 3) and may correct any remaining omitted variable bias at an individual well. According to Kennedy (2008; pp. 281-282), "Panel data can be used to deal with heterogeneity in the micro units. In any cross-section, there is a myriad of unmeasured explanatory variables that affect the behavior of the people (firms, countries, etc.) being analyzed. (Heterogeneity means that these micro units are all different from one another in fundamental unmeasured ways.) Omitting these variables causes bias in estimation. The same holds true for omitted time series variables that influence the behavior of the micro units uniformly, but differently in each time period. Panel data enable correction of this problem. Indeed, some would claim that the ability to deal with this omitted variable problem is the main attribute of panel data."

Finally, when we added the Producer Price Index for support activities for oil and gas extraction as a regressor, its sign was negative, as expected, but it hardly changed the coefficient on $I_{i}$, and certainly not in a statistically significant way. This suggests that the equity price and random well effects have adequately addressed what might otherwise be omitted variable bias in the coefficient on $I_{i}$.

Based on Eq. 1 and projecting forward 75 months, Figure 5 illustrates the rapid decline rate of Bakken Shale oil production in the early months, as well as the impact of a technological shift in production between wells where production began in August of 2015 and those where production began in August of 2018. The figure indicates the existence of a proportional upward shift in production from 2015 to 2018; the rate of production decline did not

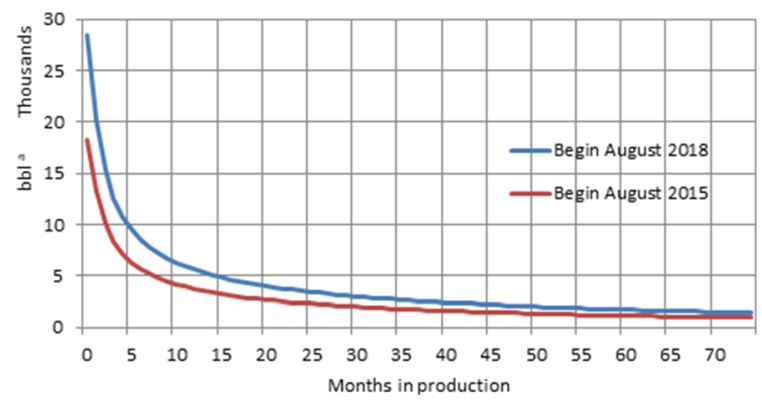

Figure 5. Expected monthly production from wells beginning production in 2015 and 2018. " "bbl" stands for "barrels," each of which contains nearly $159 \mathrm{~L}$ of crude oil. change. In fact, in the first year (12 months) of production, output in the model declined $78 \%$ for wells beginning production in 2015 and $79 \%$ for those beginning production in 2018.

In Figure 5, price, location, and distance between wells are fixed in order to isolate the effect of the technological shift, which is smaller than the quadrupling of production in the raw data mentioned under "Technological Gain," above. We conjectured that fixing location and well-spacing likely understated the technological shift, inasmuch as developers tend to "learn as they go" when progressing from one situation to the next, as noted in Attanasi and Freeman (2020). Smith (2018) used a proportional shift in the decline curve, like that in Figure 5, based on an assumption of diminishing marginal productivity of new wells. Our results helped validate his assumption.

As suggested earlier, a very general function of latitude and longitude was specified to describe well location in order to account for spatial variation in production. A flexible functional form was needed in order to approximate the irregularity in the geographic distribution of the resource attributable to naturally occurring geological dispersion and any induced spatial variation attributable to operational differences. Dummy variables for township/ range/section were considered, but the precision of latitude and longitude explained production as well as any of the dummy variables, with far fewer regressors. $45^{\circ}$ was subtracted from the values of latitude, and $100^{\circ}$ was added to the values of longitude so that they would exhibit some significant variation in relation to their means, and Stata would not omit them due to collinearity.

Table 3 shows the relative productivity of wells by geographic location. Equation 1 indicates a range of over five to one in the magnitude of the effect of location on production. In other words, when drilling moved from the most productive center of the formation, at about $(47.54,-102.68)$ to the periphery, productivity dropped substantially. Figure 6 shows the relationship between location and production after controlling for the other variables in Eq. 1. The exact center of the "sweet spot" was at $47.4939^{\circ}$ latitude and $-102.5729^{\circ}$ longitude. This was about $20 \mathrm{~km}$ from the center of the Fort Berthold Reservation, at $47.7031^{\circ}$ latitude by - 102.2978 longitude (Fig. 1).

It has been suggested that well spacing is another factor in productivity (Matthews et al., 2019). Using the PLSS, the model counted the number of 


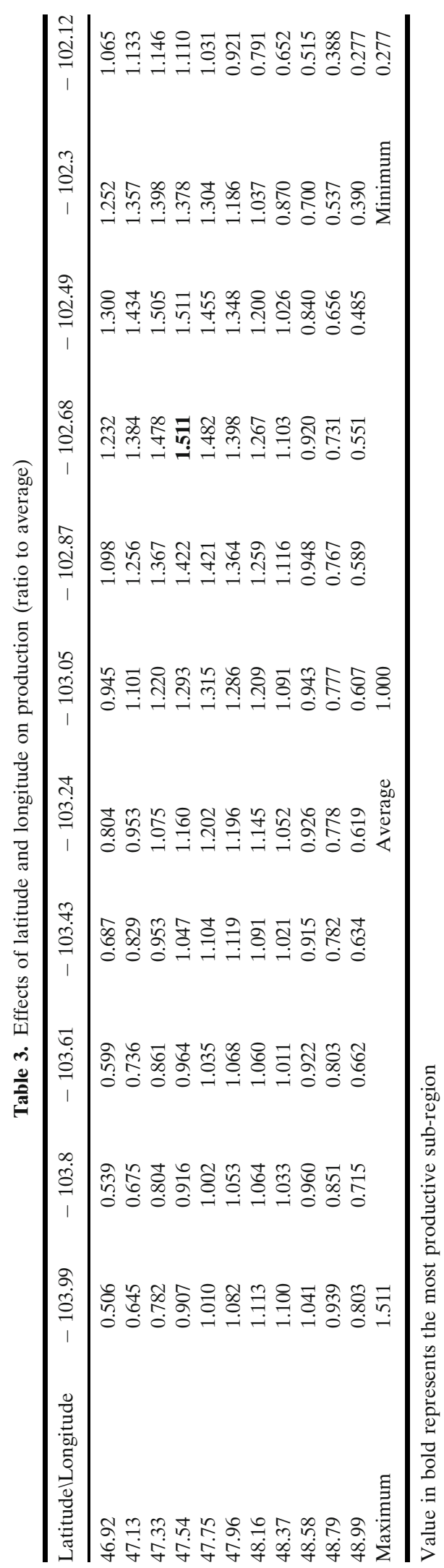




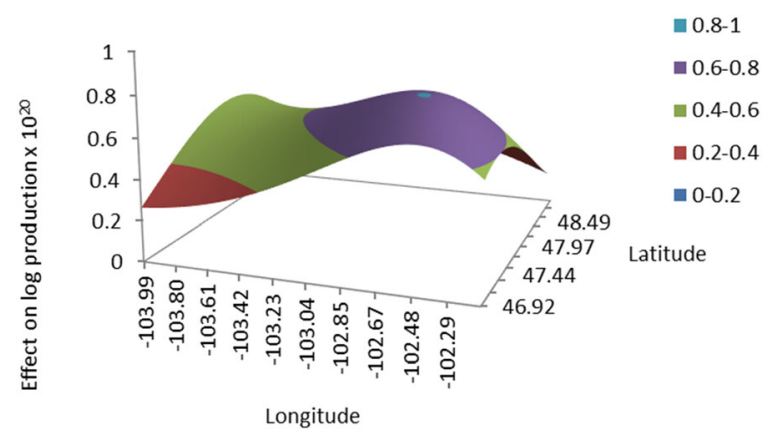

Figure 6. Effect of location on the production of Bakken Shale oil wells.

wells in each quarter-quarter section in order to estimate the impact of well spacing. To guard against endogeneity of the regressor, we used a 1month lag in the number of co-located wells. The number of co-located (in the same PLSS QQ section) wells that were in production, $W_{i t-1}$, bore a negative coefficient in Eq. 1, suggesting that, if wells were not adequately spaced, production was adversely affected, possibly as a result of interference (Ajani \& Kelkar, 2012; Jacobs, 2017; Brown et al., 2019; Matthews et al., 2019). A co-located well was counted as being "in production" if it produced more than 100 barrels. Once a well is completed, an additional co-located well reduces production at the original well by $1.65 \%$, with a $95 \%$ confidence interval of $[1.29 \%, 2.00 \%]$.

In Model 1, the coefficient on the price of equity, as measured by the first monthly lag relative to production of the Standard \& Poor's Oil \& Gas Exploration and Production Energy Trading Fund, $F_{t-1}$, was positive. Higher stock prices reflect higher expected rates of return on investment, consistent with the Hotelling (1931) pricing model and results previously reported by Smith (1981) and Bjørnland et al. (2017). Another line of reasoning is that better access to financing increases optimal spending on capital, materials, and labor and, therefore, increases supply, as in the discussion of omitted variable bias preceding Figure 5.

Note that price trended up during the sample period (Fig. 2). In fact, the correlation between log price and time was 0.66 , while the correlation between its first difference and time was only 0.10 . Hence, the log of price was used so that the supply curve would be convex, and the first difference was used to avoid spurious inference. In Eq. 1, the coefficients on the contemporaneous first difference in $\log$ price, $d p_{t}$, and its third lag, ${ }^{10} d p_{t-3}$, were positive; production increased in response to an increase in price. Further, the considerably larger coefficient on the third lag may reflect that, given more time, operators can do more in response to a change in price. With the lagged dependent variable included, the impact on production of a change in price lasting $s$ months increased over time as the sum of a geometric series (Weisstein, n.d.). To illustrate, and ignoring the effect of the third lag,

$$
\begin{aligned}
d q_{i t}= & 0.0598 d p_{t-s} \sum_{j=0}^{t-s} 0.2555^{j} \\
= & 0.0598 d p_{t-s}\left(\frac{1-0.2555^{t-s+1}}{1-0.2555}\right) \\
& \rightarrow \frac{0.0598 d p_{t-s}}{1-0.2555} \text { as } t \rightarrow \infty
\end{aligned}
$$

Even without the additional effect of the third lag, it seems clear that, given more lead time, operators can do more to change the rate of flow from a well. It is also important to consider the predictive capability of Model 1 . To predict production in the first month using Eq. 1, we let $t-1$ approach $t$ and set $M_{i}=1$, which resulted in:

$$
\begin{aligned}
q_{i}= & 72.2115-0.0221 W_{i}+0.0007 F \\
& +0.0121 I_{i}-0.0284 e^{\text {Lat }_{i}}-232.9852 e^{\text {Long }_{i}} \\
& -3.6486 \text { Lat }_{i}-18.7789 \text { Long }_{i} \\
& +5.9360 \ln \text { Lat }_{i}-98.0825 \ln \left(- \text { Long }_{i}\right) \\
& -0.6265 \text { Lat }_{i} \cdot \text { Long }_{i}
\end{aligned}
$$

In the sample, 1332 wells peaked in the first full month of production, 1275 in the second, 683 in the third, 404 in the fourth, and 243 in the fifth. It is safe to say that the first month, if it were a full month of production, would be the modal peak month. However, to avoid the problem of mid-month starts, we set the second month as the first full month in Model 1.

Table 4 shows the predicted production in the second month falling between the median and mean in the sample, lending some credence to the model. In this example, location was fixed at $47.9242^{\circ}$ latitude and $-103.1173^{\circ}$ longitude. For all but 1 month (September, 2017), median production for wells in the second month was below the mean, and the average mean-to-median ratio across months was

\footnotetext{
${ }^{10}$ Other lags were either not significant or did not have the expected sign.
} 
Table 4. Summary statistics for the second month of production (bbl/month)

\begin{tabular}{lccc}
\hline & Median & Prediction & Mean \\
\hline September 2015 & 12,054 & 13,305 & 13,439 \\
September 2018 & 19,968 & 20,168 & 23,254 \\
\hline
\end{tabular}

"bbl" stands for "barrels," each of which contains nearly $159 \mathrm{~L}$ of crude oil

1.12. Over the 49-month sample period, median production in the second month of production increased by $66 \%$, and the mean increased by $73 \%$.

\section{Price Elasticity Under Model 1}

Oil supply price elasticity has been approached from a variety of perspectives and contexts, and it continues to be of considerable interest to the petroleum industry, especially given the volatility of price since 1973. Using a series of simulations, Ikonnikova et al. (2017) showed that "the oil price is probably the single most important factor that can drive cumulative Bakken production (2015-2045) up or down as much as $50 \%$." As also demonstrated here, an important application of the econometric modeling was to estimate the price elasticity for the Bakken Shale. Table 5 summarizes the estimates of Bakken Shale oil supply price elasticity obtained using Model 1, with their 95\% confidence intervals. The entries in Table 5 represent the percent changes in production after the indicated number of months resulting from a one percent change in price lasting that length of time. For example, if price rises by one percent for 5 months, production 5 months after the onset of that change would be $0.31 \%$ higher than it would have been without the change in price.

\section{Model 2: Discontinuous Production}

Model 1 assumes that wells are continuously in production (i.e., there are no gaps), a constraint that excludes actual operating situations associated with completing, shutting in, and restarting wells, which may involve full months of no production. Excluding observations of zero production is largely benign for the purpose of estimating a continuous production curve like that shown in Figure 4. However, gaps in production, including when they begin, how long they continue, and when they end, to some degree reflect the impact of price, even if that is not the main consideration. This connection was evident in the following response to low prices during Spring 2020:

Louisiana Oil and Gas Association President Gifford Briggs said the group is in the process of updating ... projections in light of the recent price crash. "Our members are telling me that they've instructed their field people to begin shutting in production immediately," he said (Mackrael et al., 2020).

An opposite response became apparent with a rapid rebound in activity as prices increased in June 2020:

U.S. shale producers are expected to restore roughly half a million barrels per day (bpd) of crude output by the end of June, according to crude buyers and analysts, amounting to a quarter of what they shut-in since the coronavirus pandemic cut fuel demand and hammered oil prices.

Such a swift rise in U.S. production would complicate efforts by top producers Saudi Arabia and Russia to encourage global allies to fulfill their pledges to make record production cuts...

U.S. producers cut supply by roughly two million bpd. But the recovery in benchmark oil prices to around $\$ 40$ a barrel makes some shale output profitable again, even though that level is unlikely to spur additional new drilling activity. Larger producers are re-opening the taps in lowcost plays in Texas, but also in expensive shale basins in North Dakota and Oklahoma (Kumar \& Hiller, 2020).

In the longer term, producers may respond to changing conditions by scheduling and re-scheduling drilling and completion, shutting in and restarting wells, and modulating production at wells that are up and running. Operators may also choose to delay completion of drilled wells until prices improve. The US Energy Information Administration (EIA) noted, as crude oil prices fell in the second half of 2014 and remained low in 2015, the count of new wells drilled in North Dakota fell. During that time, the time to drill a new well remained relatively unchanged, but the time to complete a well increased from about 3 months to nearly a year (EIA, 2019). All of these behaviors enhance shale oil's role as a balance wheel to the larger oil market. 
Table 5. Estimated supply price elasticity for Bakken Shale oil in North Dakota based on Model 1 (response to a $1 \%$ change in price)

\begin{tabular}{lccc}
\hline Response time (months) & Elasticity $(\% \Delta$ in production) & \multicolumn{2}{c}{$95 \%$ Confidence bounds (\% $\Delta$ in production) } \\
\cline { 3 - 4 } & & Lower & Upper \\
\hline 1 & 0.06 & 0.02 & 0.09 \\
5 & 0.08 & 0.03 & 0.13 \\
8 & 0.31 & 0.24 & 0.38 \\
\hline
\end{tabular}

\section{Estimation of Model 2}

For purposes of constructing Model 2, production was assumed to be one barrel during months when production was actually zero, so that the dependent variable, the log of production, would be defined. The variation between one barrel and observations over 100 barrels was virtually the same as between zero barrels and the same observations over 100 barrels. Months from peak production was excluded because observations of zero production before completion have nothing to do with the number of months until peak production occurs. Similarly, the timing of the initial month of production (though not production in that month) was excluded because, when drilling and completion costs are variable, so is the timing of completion; and the later completion occurs, the higher the production, since improved technology can be used. In this case, the timing of initial production would be an endogenous regressor, correlated with innovations in production. Hence, for simplicity, it was omitted. Instead, we controlled for technological progress using a common deterministic trend.

As in the case of Model 1, we tried a random effects modeling approach. However, we found that the random effects explained almost none of the variance in production, whereas a pooled ordinary least squares (OLS) approach produced the same coefficients to five decimal places. Neither running 10,000 bootstrap replications nor down-weighting high-variance observations nor iterating the variance-covariance matrix and coefficients improved inference, and so we invoked Occam's Razor. We took OLS to be efficient under a heteroscedasticityand autocorrelation-robust error structure and used it to estimate Eq. 4. The full Stata header is shown in Table 9 in the appendix.
Model 2 Results

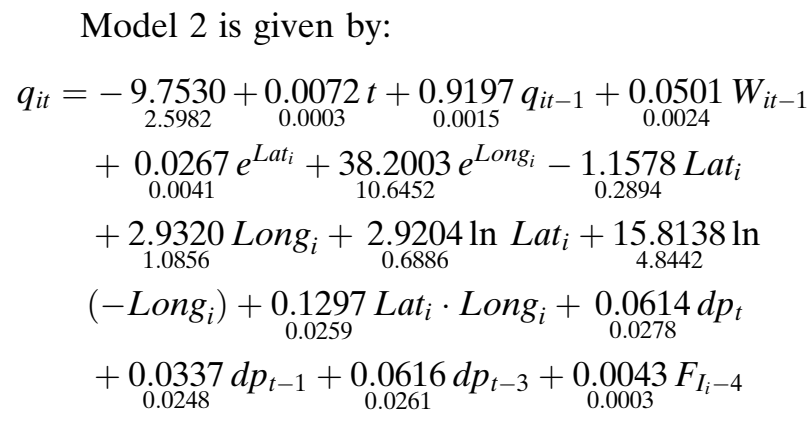

The coefficient on the deterministic trend, 0.0072 , was highly significant $(p<0.0001)$, though somewhat smaller than that on initial month of production in Eq. 1. Both models may be interpreted to depict rapid technological progress. We again addressed potential omitted variable bias by including the price of equity, $F_{I_{i}-4}$ and by trying a model with random well effects. That the data indicated that the intercept term did not differ by well was consistent with there being no such bias in Eq. 4. At 0.9197, persistence, the coefficient on $q_{i t-1}$, was considerably larger than in Eq. 1. This likely reflects the greater costs associated with shutting in and restarting wells, as compared to those of simply modulating continuous production.

The coefficient on co-located wells, $W_{i t-1}$, was positive, in contrast to that in Eq. 1, which is negative. This implies that, when a well has been drilled, as in Eq. 1, adding wells nearby lowers production (Ajani \& Kelkar, 2012; Pang et al., 2015; Ajisafe et al., 2017), but when choosing where to drill, as in Eq. 4, it is advised to drill where others have drilled already. In Eq. 1, the addition of a nearby well lowers output of the original well by $1.65 \%$. In Eq. 4, one can expect $5.01 \%$ more output from a prospective well for each nearby existing well, with a $95 \%$ confidence interval of $[4.54 \%, 5.48 \%]$. This is 
an interesting twist on the common resource problem, suggesting that unitization of shale plays (or portions thereof) could lead to a Pareto improvement, if it could be technically and legally accomplished (De Kok, 2014; Kramer, 2015; Kleit et al., 2020).

The coefficient on the stock price, lagged 4 months before the date of initial production (as distinct from current production, as in Eq. 1), $F_{I_{i}-4}$, was positive. This implies that when capital is more available, more is invested, and production is increased. We used the 4-month lag because a period of time shorter than this would not allow for much change in the physical investment necessary to complete a well. Inasmuch as the costs of these investments were correlated with prices in markets for inputs large enough for financial traders to notice, like operating costs for fluid, proppant, and labor, a rise in the cost of such inputs that is expected at Time $I_{i}-4$ will both shift the supply curve up, decreasing production, $q_{i t}$, at any given price for oil, $p_{t}$, and lower the present value of expected profits, lowering the stock price, $F_{I_{i}-4}$, and so its coefficient was positive. The fact that random well effects, which would stand in for any omitted variables, were found to be superfluous supports the adequacy of the regressors in Model 2, including $F_{I_{i}-4}$, as a representation of cost.

Because random effects were needed in Model 1, which differed from Model 2 mainly in that months of zero production were omitted from the data, the random effects in Model 1 likely only reflect differences across wells related to shut-ins, restarts, and the timing of completion, insofar as the differences related to completion are not monotonically related to time; the date of completion was not an omitted variable in Model 1.

\section{Price Elasticity Under Model 2}

Table 6 reports the estimates of supply price elasticity for Bakken Shale oil based on Model 2 (discontinuous production), along with their 95\% confidence intervals. Recall that Model 2 encompasses situations of zero production associated with various well shut-in/re-start scenarios, as well as observations preceding completions of wells.

Note that the values reported in Table 6 are higher than those reported in Table 5, reflecting the greater response to a change in price when stopping and starting production is possible, in contrast to a situation wherein completion/shut-in/re-start scenarios are not considered, except in the month when production begins or ends. ${ }^{11}$ The more options one has for changing production, the greater the change in production in response to a given change in price. Further, the coefficients on $d p_{t}$ in Eqs. 1 and 4 were not appreciably different, suggesting that it takes more than a few weeks of higher prices for an operator to respond positively by completing or restarting a well, and more than a few weeks of lower prices for an operator to respond negatively by shutting one in. Significantly, around $85 \%$ of the supply impact occurred within the first 2 years, again pointing toward shale oil's important role as a balance wheel to the oil market.

\section{Evaluating Model 2 Results in Light of Prior Elas- ticity Estimates}

Work specifically focused on the price elasticity of shale oil is still somewhat limited, which our analysis and results help alleviate. A popular approach has been to calculate a breakeven point (BEP) for the price of shale oil (Business Insider, 2014), which Kleinberg et al. (2016) clarified. Ansari and Kaufman (2019) followed with a different BEP calculation and concluded that production is most sensitive to price changes near that point. Our approach is somewhat different from these two in the sense that we sought to specifically quantify the price elasticity of tight oil supply. Put another way, low oil prices slow down shale oil development, and high prices accelerate it. And, as this research has demonstrated, breakeven points can shift dramatically in a few years due to rapid technological progress. Our approach is more closely aligned with that of Smith and Lee (2017) who estimate elasticity of economically recoverable reserves of shale oil, though we do not explicitly model that variable.

Bjørnland et al. (2017) also estimated elasticity of tight oil supply using North Dakota data, but with the following differences in time span and modeling approach. Their data end in 2015, about when ours begin. They used (1) the price of WTI, while we used first purchase price in North Dakota, (2) a combi-

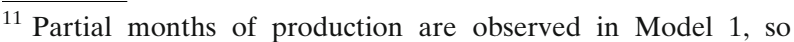
instances of starting and stopping production within such a month affect the total monthly production, and this may occur in response to a change in price.
} 
Table 6. Estimates of supply price elasticity for Bakken Shale oil in North Dakota, with $95 \%$ confidence intervals, based on Model 2 (response to a $1 \%$ change in price)

\begin{tabular}{|c|c|c|c|}
\hline \multirow[t]{2}{*}{ Response time } & \multirow[t]{2}{*}{ Elasticity ( $\% \Delta$ in production) } & \multicolumn{2}{|c|}{$95 \%$ Confidence bounds ( $\% \Delta$ in production) } \\
\hline & & Lower & Upper \\
\hline 1 month & 0.06 & 0.01 & 0.12 \\
\hline 3 months & 0.23 & 0.08 & 0.39 \\
\hline 5 months & 0.50 & 0.20 & 0.80 \\
\hline 7 months & 0.72 & 0.29 & 1.16 \\
\hline 9 months & 0.91 & 0.37 & 1.46 \\
\hline 1 year & 1.14 & 0.46 & 1.83 \\
\hline 2 years & 1.65 & 0.66 & 2.65 \\
\hline 3 years & 1.84 & 0.73 & 2.95 \\
\hline 4 years & 1.91 & 0.76 & 3.06 \\
\hline 8 years & 1.95 & 0.78 & 3.13 \\
\hline
\end{tabular}

nation of current and futures prices, while we found lagged "spot" prices and oil and gas equity prices, which vary directly with expected oil prices, to be significant predictors of production, (3) fixed time effects, while we used completion date or a deterministic trend, and (4) effects of location aggregated into fixed effects on wells, while we specified several transformations of latitude and longitude. In addition, Bjørnland et al. (2017) did not control for well density, while we found that it informs the problem of common resources. Both approaches lead to essentially the same qualitative conclusions. They find support for Hotelling's (1931) theory of optimal extraction, while we found that production depends positively on common stock prices for extraction of oil and gas, and, moreover, "firms using shale oil technology are more flexible in allocating output intertemporally."

Estimates of supply price elasticity for the more general category of non-OPEC crude oil are much lower, especially in the short term. For example, Golombek et al. (2018), Alhajji and Huettner (2000), and Vatter (2017) all had previously estimated the price elasticity of non-OPEC oil supply, of which shale oil represents a subset. Golombek et al. (2018) estimated the long-run price elasticity of non-OPEC supply to be 0.32 , citing Alhajji and Huettner (2000), who estimated it to be 0.29, whereas Vatter (2017) estimated it to be 0.24. By way of contrast, the last row in Table 6 shows a much larger value of 1.95 . A current productionweighted average of our estimate of long-run elasticity of tight oil supply of 1.95 and conventional non-OPEC supply of 0.24 comes out to 0.53 , indicating that shale oil has made non-OPEC supply much more elastic, but still decidedly inelastic. Vatter (2017) further estimated within-quarter elasticity of non-OPEC supply to be 0.015 , well below the 3-month estimate of 0.23 in Table 6 .

\section{Testing Model 2 Against Three Sources of Aggregate US Shale Oil Production}

As a test of the robustness of Model 2, Table 7 shows how Eq. 4 performs out of sample, when applied to three different sources of aggregate US shale oil production: Bakken (North Dakota plus Montana); Permian Spraberry; and all US shale oil combined. Here, we used aggregate monthly data because more granular information was not universally available throughout the USA. ${ }^{12}$ Time-invariant variables and well density, assumed not to change, were represented in a constant, which is shown in the last row, and calibrated to provide a prediction for May 2019. None of the projected errors exceeded $8 \%$. For reasons suggested by Coburn and Attanasi (2020), the model did a better job predicting aggregate US production than it does for the Bakken (North Dakota plus Montana) alone. Predictions for the Permian were almost as good as those for the Bakken (North Dakota plus Montana). It is not unreasonable, then, to generalize our results from the Bakken to other shale plays in North America.

\footnotetext{
${ }^{12}$ Coburn and Attanasi (2021) addressed various issues associated with using aggregate data.
} 
Table 7. Projection for Bakken, Permian, and Total US tight oil production (MMb/d) ${ }^{\mathrm{a}}$

\begin{tabular}{|c|c|c|c|c|c|c|c|c|c|c|c|c|}
\hline & \multicolumn{4}{|c|}{ Spraberry (Permian) } & \multicolumn{4}{|c|}{ Bakken (ND and MT) } & \multicolumn{4}{|c|}{ Total US tight oil } \\
\hline & Actual & Projection & $\begin{array}{c}\text { Error } \\
(\%)\end{array}$ & $\begin{array}{c}\text { Abs Err } \\
(\%)\end{array}$ & Actual & Projection & $\begin{array}{c}\text { Error } \\
(\%)\end{array}$ & $\begin{array}{c}\text { Abs Err } \\
(\%)\end{array}$ & Actual & Projection & $\begin{array}{c}\text { Error } \\
(\%)\end{array}$ & $\begin{array}{c}\text { Abs Err } \\
(\%)\end{array}$ \\
\hline 19-May & 1.58 & 1.58 & & & 1.38 & 1.38 & & & 7.56 & 7.56 & & \\
\hline 19-Jun & 1.60 & 1.61 & 0.20 & 0.20 & 1.40 & 1.36 & -3.20 & 3.20 & 7.62 & 7.61 & -0.10 & 0.10 \\
\hline 19-Jul & 1.63 & 1.67 & 2.00 & 2.00 & 1.42 & 1.38 & -3.30 & 3.30 & 7.74 & 7.79 & 0.70 & 0.70 \\
\hline 19-Aug & 1.67 & 1.72 & 2.60 & 2.60 & 1.46 & 1.39 & -5.00 & 5.00 & 7.87 & 7.94 & 0.90 & 0.90 \\
\hline 19-Sep & 1.67 & 1.73 & 3.90 & 3.90 & 1.42 & 1.37 & -3.80 & 3.80 & 7.97 & 7.95 & -0.20 & 0.20 \\
\hline 19-Oct & 1.68 & 1.79 & 6.50 & 6.50 & 1.50 & 1.38 & -7.60 & 7.60 & 8.11 & 8.13 & 0.30 & 0.30 \\
\hline 19-Nov & 1.73 & 1.84 & 6.30 & 6.30 & 1.50 & 1.39 & -6.90 & 6.90 & 8.10 & 8.25 & 1.80 & 1.80 \\
\hline 19-Dec & 1.76 & 1.88 & 6.60 & 6.60 & 1.46 & 1.41 & -3.30 & 3.30 & 8.11 & 8.37 & 3.20 & 3.20 \\
\hline 20-Jan & 1.80 & 1.92 & 6.90 & 6.90 & 1.41 & 1.41 & 0.30 & 0.30 & 8.12 & 8.51 & 4.70 & 4.70 \\
\hline Average & & & 4.40 & 4.40 & & & -4.10 & 4.20 & & & 1.40 & 1.50 \\
\hline Constant: & & $(0.42)$ & & & & $(0.46)$ & & & & $(0.31)$ & & \\
\hline
\end{tabular}

a“"MMb/d" stands for "million barrels per day"; each barrel contains nearly $159 \mathrm{~L}$ of crude oil

Source: EIA monthly drilling productivity report

\section{CONCLUSIONS AND FURTHER DISCUSSION}

As stated in the introduction, our work does not fully address the many questions pertaining to shale oil resources and their role in global markets. However, using the Bakken Shale as a case study, our work yielded important insights into the productivity and price sensitivity associated with well development within shale plays that inform knowledge of the resource, its ongoing development, and its ultimate role in global energy markets.

We conclude that technological progress in the Bakken Shale and, by extension, other shale plays, was rapid. Analysis of horizontal well production data has revealed significant technological progress over a 4-year period; so much so that it offset a major production decline that would have been expected following a drop in drilling. Nonetheless, oil is a depletable resource, and, at some point, there must be diminishing returns. For the time being, however, oil prices will largely determine the pace of shale oil development in the USA.

We found that this source of supply is more price-elastic than non-OPEC supply in general. It is said that the Bakken is the most price-sensitive of the shale plays (Clemente, 2018), but, inasmuch as the greater elasticity of the Bakken is indicative of the supply of shale oil in general, it is good news for the world's consumers and the world economy, as greater elasticity of supply dampens extreme price swings. Because of the asymmetric effects of oil prices on the macroeconomy (Mork, 1994), those price swings lower world GDP, and so shale oil's dampening of them raises world GDP. Consistently, Melek et al (2020) "show that the shale boom boosted U.S. real GDP by a little more than 1 percent" [abstract]. Our formal results underscored the important role of shale oil in the coming decades in balancing global supplies with demand. The range of high and low prices is likely to be smaller than it otherwise would have been, and, ultimately, oil prices and the increasing, long-run marginal cost of developing the shale resource will tend to converge. However, despite the greater elasticity of shale oil supply, at current production levels, non-OPEC supply as a whole remains decidedly inelastic.

Assessing shale oil's future potential starts with the recognition that, so far, development has been constrained to regions with historic oil production, such as the Williston Basin. This may be due to the industry's familiarity with historic producing areas, but most likely it is simply due to geology. Virtually all of the production is located in well-known oil regions. Indeed, $89 \%$ of shale oil production is from source rock supporting the Permian, Bakken, and East Texas conventional plays. Consequently, while shale oil has proven to be prolific, it remains concentrated in a few regions in which substantial conventional reserves were previously found. This observation hints at the future for shale oil in other countries and the impact it may have in the global arena. 
Continued production of tight oil may also be consistent with optimal climate policy. Vatter (2021) argued that optimal tax rates on emissions of $\mathrm{CO}_{2}$ are progressive, they vary directly with the wealth of the taxpayer, and against policy mechanisms that apply "at the source" for oil, because the latter raise prices by the same absolute amount for all consumers, including the poor, which is regressive.

\section{ACKNOWLEDGMENTS}

We thank participants at the concurrent session of the IAEE conference in Montreal in 2019, Ron Ripple and Jim Smith in particular, for their constructive feedback. We thank Elizabeth Ferreira for monitoring coverage of current events relevant to our research. We thank the staff at Bonhoeffer's Café and Espresso in Nashua, where Vatter did much of his work. We thank the state of North Dakota and the US Energy Information Administration for making such excellent data available at no cost to the user. We thank our anonymous reviewers, who work only for truth, not wealth or glory.

\section{APPENDIX: STATA OUTPUT}

Tables 8 and 9 contain the Stata output pertaining to Models 1 and 2, which involve parameter estimation based on continuous and discontinuous (including months of zero) production, respectively.

Table 8. Stata header for Model 1; estimation using continuous production (observations of zero production excluded)

\begin{tabular}{|c|c|c|c|c|c|c|}
\hline \multicolumn{5}{|c|}{$\begin{array}{l}\text { Random effects GLS regression } \\
\text { Group variable: Well } \\
R \text {-sq: within }=0.5644 \\
\text { between }=0.7964 \\
\text { overall }=0.6557 \\
\text { Random effects } u \_i \sim \text { Gaussian } \\
\text { corr }\left(u \_i, X\right)=0 \text { (assumed) }\end{array}$} & \multicolumn{2}{|c|}{$\begin{array}{l}\text { Number of obs }=94,359 \\
\text { Number of groups }=4261 \\
\text { Obs per group: } \min =1 \\
\text { avg }=22 \\
\max =48 \\
\text { Wald chi2 }(15)=143,668 \\
\text { Prob }>\operatorname{chi} 2=0.000\end{array}$} \\
\hline$q$ & \multirow{2}{*}{$\begin{array}{r}\text { Coefficient } \\
-0.0037\end{array}$} & \multirow{2}{*}{$\frac{\text { Robust Std. Err. }}{0.0003}$} & \multirow{2}{*}{$\frac{z}{-11.18}$} & \multirow{2}{*}{$\frac{P>z}{0.000}$} & \multicolumn{2}{|c|}{ [95\% Confidence Interval] } \\
\hline$M_{i t}$ & & & & & -0.0044 & -0.0031 \\
\hline$m_{i t}$ & -0.4472 & 0.0046 & -98.26 & 0.000 & -0.4561 & -0.4382 \\
\hline$I_{i}$ & 0.0090 & 0.0003 & 27.67 & 0.000 & 0.0084 & 0.0097 \\
\hline$W_{i t-1}$ & -0.0165 & 0.0018 & -9.01 & 0.000 & -0.0200 & -0.0129 \\
\hline$d p_{t}$ & 0.0598 & 0.0179 & 3.35 & 0.001 & 0.0248 & 0.0948 \\
\hline$d p_{t-3}$ & 0.1847 & 0.0173 & 10.65 & 0.000 & 0.1508 & 0.2187 \\
\hline$F_{t-1}$ & 0.0006 & 0.0003 & 2.06 & 0.039 & 0.0000 & 0.0011 \\
\hline$q_{i t-1}$ & 0.2555 & 0.0052 & 49.14 & 0.000 & 0.2453 & 0.2657 \\
\hline$e^{L a t_{\mathrm{i}}}$ & -0.0211 & 0.0067 & -3.15 & 0.002 & -0.0343 & -0.0080 \\
\hline$e^{\text {Long }_{i}}$ & -173.4584 & 19.2171 & -9.03 & 0.000 & -211.1232 & -135.7937 \\
\hline Lat $_{i}$ & -2.7164 & 0.4644 & -5.85 & 0.000 & -3.6266 & -1.8062 \\
\hline Long $_{i}$ & -13.9810 & 1.9704 & -7.10 & 0.000 & -17.8430 & -10.1190 \\
\hline $\ln L a t_{i}$ & 4.4193 & 1.1299 & 3.91 & 0.000 & 2.2049 & 6.6338 \\
\hline $\ln \left(-\right.$ Long $\left._{i}\right)$ & -73.0228 & 8.7841 & -8.31 & 0.000 & -90.2393 & -55.8063 \\
\hline Lat $_{i} \cdot$ Long $_{i}$ & -0.4665 & 0.0444 & -10.51 & 0.000 & -0.5535 & -0.3794 \\
\hline _cons & 53.7654 & 4.7054 & 11.43 & 0.000 & 44.5431 & 62.9878 \\
\hline$\sigma_{u}$ & 0.2249 & & & & & \\
\hline$\sigma_{e}$ & 0.4777 & & & & & \\
\hline$\rho$ & 0.1814 & & & & ion of varian & $\left.u_{i}\right)$ \\
\hline
\end{tabular}


Table 9. Stata header for Model 2; estimation using discontinuous production (observations of zero production included)

\begin{tabular}{|c|c|c|c|c|c|c|}
\hline \multirow{3}{*}{$\frac{q}{W_{i t-1}}$} & \multirow{3}{*}{$\frac{\text { Coefficient }}{0.0501}$} & \multirow{3}{*}{$\frac{\text { Robust Std. Err. }}{0.0024}$} & \multirow{3}{*}{$\frac{z}{20.86}$} & \multirow{3}{*}{$\frac{P>z}{0.000}$} & \multirow{2}{*}{\multicolumn{2}{|c|}{$\begin{array}{l}\text { Number of obs }=201,638 \\
F(14,201,623)=. \\
\text { Prob }>F=0 \\
R \text {-squared }=0.92 \\
\text { Root MSE }=1.23 \\
\text { [95\% Confidence Interval }]\end{array}$}} \\
\hline & & & & & & \\
\hline & & & & & 0.0454 & 0.0548 \\
\hline$d p_{t}$ & 0.0614 & 0.0278 & 2.21 & 0.027 & 0.0070 & 0.1158 \\
\hline$d p_{t-1}$ & 0.0337 & 0.0248 & 1.36 & 0.174 & -0.0149 & 0.0822 \\
\hline$d p_{t-3}$ & 0.0616 & 0.0261 & 2.36 & 0.018 & 0.0104 & 0.1128 \\
\hline$F I_{\mathrm{i}-4}$ & 0.0043 & 0.0003 & 12.91 & 0.000 & 0.0037 & 0.0050 \\
\hline$t$ & 0.0072 & 0.0003 & 25.63 & 0.000 & 0.0066 & 0.0077 \\
\hline$q_{i t-1}$ & 0.9197 & 0.0015 & 617.63 & 0.000 & 0.9167 & 0.9226 \\
\hline$e^{L a t_{i}}$ & 0.0267 & 0.0041 & 6.46 & 0.000 & 0.0186 & 0.0347 \\
\hline$e^{\text {Long }_{i}}$ & 38.2003 & 10.6452 & 3.59 & 0.000 & 17.3362 & 59.0644 \\
\hline$L a t_{i}$ & -1.1578 & 0.2894 & -4.00 & 0.000 & -1.7249 & -0.5906 \\
\hline Long $_{i}$ & 2.9320 & 1.0856 & 2.70 & 0.007 & 0.8044 & 5.0597 \\
\hline $\ln \mathrm{Lat}_{i}$ & 2.9204 & 0.6886 & 4.24 & 0.000 & 1.5708 & 4.2700 \\
\hline $\ln \left(-\right.$ Long $\left._{i}\right)$ & 15.8138 & 4.8442 & 3.26 & 0.001 & 6.3193 & 25.3083 \\
\hline Lat $_{i}$ Long $_{i}$ & 0.1297 & 0.0259 & 5.01 & 0.000 & 0.0790 & 0.1804 \\
\hline _cons & -9.7530 & 2.5982 & -3.75 & 0.000 & -14.8454 & -4.6607 \\
\hline
\end{tabular}

\section{REFERENCES}

Ajani, A., \& Kelkar, M. (2012). Interference study in shale plays. In SPE 151045, SPE hydraulic fracturing technology conference, The Woodlands, TX (February 6-8).

Ajisafe, F., Solovyeva, I., Morales, A., Ejofodomi, E., \& Porcu, M. M. (2017). Impact of well spacing and interference on production performance in unconventional reservoirs, Permian Basin. In URTeC 29690466, unconventional resources technology conference, Austin, TX (July 24-26).

Alhajji, A. F., \& Huettner, D. (2000). OPEC and world crude oil markets from 1973 to 1994: Cartel, oligopoly, or competitive? Energy Journal, 21(3), 31-60.

Alibaba. (n.d.). https://www.alibaba.com/showroom/hydraulic-fra cturing-fluids.html. Accessed 24 June 2021.

Ansari, E., \& Kaufmann, R. (2019). The effect of oil and gas price and price volatility on rig activity in tight formations and OPEC strategy. Nature Energy, 4, 321-328.

Attanasi, E. D., Coburn, T. C., \& Ran-McDonald, B. (2019). Statistical detection of flow regime changes in horizontal hydraulically fractured Bakken oil wells. Natural Resources Research, 28(1), 259-272.

Attanasi, E. D., \& Freeman, P. A. (2020). Growth drivers of Bakken oil well productivity. Natural Resources Research, 29, 1471-1486.

Attanasi, E. D., Freeman, P. A., \& Coburn, T. C. (2020a). Well predictive performance of play-wide and subarea random forest models for Bakken productivity. Journal of Petroleum Science and Engineering, 191, 107-150.

Attanasi, E. D., Freeman, P. A., \& Coburn, T. C. (2020b). Comparison of machine learning approaches used to identify the driers of Bakken oil well productivity. Statistical Analysis and Data Mining. https://doi.org/10.1002/sam.11487.

Bader, J. W., LeFever, J. A., Nesheim, T. O., \& Stolldorf, T. D. (2018). Bakken-Three Forks formations, Madison group, spearfish formation. geological investigation No. 208, North Dakota geological survey. In 26th Williston basin petroleum conference, Bismarck, ND (May 22-24). https://www.dmr.n d.gov/ndgs/documents/Publication_List/pdf/GEOINV/GI-20 8.pdf. Accessed 27 February 2021.

Baltagi, B. H. (2008). Econometric analysis of panel data (4th ed.). Wiley.

Bjørnland, H., Nordvik, F., \& Rohrer, M. (2017). Supply flexibility in the shale patch: Evidence from North Dakota, Norges Bank. Working Paper, September. https://doi.org/10.2139/ssr n.3003086.

Brown, J., Christ, F., \& Grace, T. (2019). Value over volume: Shale development in the era of cash. McKinsey \& Company, $\mathrm{h}$ ttps://www.mckinsey.com/ /media/McKinsey/Industries/Oi 1\%20and\%20Gas/Our\%20Insights/Value \%20over\%20vo lume $\% 20$ Shale $\% 20$ development $\% 20$ in $\% 20$ the $\% 20$ era $\% 20$ o $\mathrm{f} \% 20 \mathrm{cash} /$ Value-over-volume-Shale-development-in-the-er a-of-cash.pdf. February 27 Accessed 2021.

Clemente, J. (2018). The great Bakken oil rebound. Forbes. h ttps://www.forbes.com/sites/judeclemente/2018/05/16/the-gre at-bakken-oil-rebound/\#b6de3a85a543. Accessed 2 March 2019.

Coburn, T. C., \& Attanasi, E. D. (2020). Implications of aggregating and smoothing daily production data on estimates of the transition time between flow regimes in horizontal hydraulically fractured Bakken oil wells. Mathematical Geosciences, 53(6), 1261-1292.

Covert, T. R. (2015). Experiential and social learning in firms: The case of hydraulic fracturing in the Bakken Shale, February 22. SSRN Electronic Journal. https://doi.org/10.2139/ssrn.248 1321.

De Kok, A. L. (2014). Pooling and unitization methods across shale basins (or lack thereof): Overview of pooling and unitization in North Dakota. In Development Issues in Major Shale Plays: What's on the Horizon. Rocky Mountain Mineral 
Law Foundation and American Association of Petroleum Landmen, Mineral Law Series 2.

Denney, D. (2011). Ranking production potential from key geological drivers-Bakken case study. Journal of Petroleum Technology, 63, 63-65.

Diggle, P. J., Heagerty, P., Liang, K.-Y., \& Zeger, S. L. (2002). Analysis of longitudinal data (2nd ed.). Oxford University Press.

EIA. (2018). Today in energy (January 30): Hydraulically fractured horizontal wells account for most new oil and natural gas wells. https://www.eia.gov/todayinenergy/detail.php?id=3 4732\#: : text=The $\% 20$ combination $\% 20$ of $\% 20$ horizontal $\% 20$ drilling,condensate $\% 2 \mathrm{C} \% 20$ and $\% 20$ natural $\% 20$ gas $\% 20$ pro duction.\&text=Although $\% 20$ horizontal\%20drilling $\% 20$ has $\% 20$ been,growing $\% 20$ in $\% 20$ the $\% 20$ early $\% 202000$ s. Accessed 11 September 2020.

EIA. (2020a). Refiner acquisition cost of crude oil. https://www.e ia.gov/dnav/pet/pet_pri_rac2_dcu_nus_m.htm. Accessed 8 November 2020

EIA. (n.d.a). https://www.eia.gov/dnav/pet/hist/LeafHandler.ashx $? \mathrm{n}=$ pet $\& \mathrm{~s}=\mathrm{mttntus} 2 \& \mathrm{f}=\mathrm{m}$. Accessed 10 December 2020 .

EIA. (n.d.b). https://www.eia.gov/petroleum/drilling/. Accessed 19 March 2019.

EIA. (n.d.c). Data, petroleum and other liquids. https://www.eia.g ov/petroleum/data.php. Accessed 18 October 2020.

EIA (U.S. Energy Information Administration). (2019). Today in energy (December 5): U.S. petroleum exports exceed imports in September. https://www.eia.gov/todayinenergy/detail.php? $\mathrm{id}=42176$. Accessed 22 July 2020.

Federal Reserve Bank of Saint Louis data portal; FRED. (n.d.). h ttps://fred.stlouisfed.org/. Accessed 11 August 2021.

Fitzgerald, T. (2015). Experiential gains with a new technology: An empirical investigation of hydraulic fracturing. Agricultural and Resource Economics Review, 44(2), 83-105.

Freeman, D. A. (2006). On the so-called "Huber sandwich estimator" and "robust standard errors." The American Statistician, 60(4), 299-302.

Frees, E. (2004). Longitudinal and panel data: Analysis and applications in the social sciences. Cambridge University Press.

Gaswirth, S. B., \& Marra, K. R. (2015). U.S. geological survey 2013 assessment of undiscovered resources in the Bakken and Three Forks Formations of the U.S. Williston Basin Province. American Association of Petroleum Geologists Bulletin, 99, 639-660.

Gaswirth, S. B., Marra, K. R., Cook, T. A., et al. (2013). Assessment of undiscovered oil resources in the Bakken and Three Forks formations, Williston Basin Province, Montana, North Dakota, and South Dakota. U.S. Geological Survey Fact Sheet 2013-2013, April. https://pubs.usgs.gov/fs/2013/3013/fs 2013-3013.pdf. Accessed 27 February 2021.

Golombek, R., Irarrazabal, A., \& Ma, L. (2018). OPEC's market power: An empirical dominant firm model for the oil market. Energy Economics, 70, 98-115.

Hanewald, C. (2017). The death of OPEC? The displacement of Saudi Arabia as the world's swing producer and the futility of an output freeze. Indiana Journal of Global Legal Studies, 24(1), 277-308.

Hausman, J. (1978). Specification tests in econometrics. Econometrica, 46, 1251-1271.

Hotelling, H. (1931). The economics of exhaustible resources. Journal of Political Economy, 39(137), 175.

Hsiao, C. (2003). Analysis of panel data (2nd ed.). Cambridge University Press.

Ikonnikova, S., Gülen, G., \& Browning, J. (2017). Bakken production outlook sensitivity and uncertainty analysis. In Unconventional resources technology conference, Austin, Texas, USA, 24-26, July. https://doi.org/10.15530/URTEC-2 017-2670156.
Jacobs, T. (2017). Frac hits reveal well spacing may be too tight, completion volumes too large. Journal of Petroleum Technology, 69, 35-37.

Kabir, C. S., Rasdi, F., \& Igboalisi, B. (2011). Analyzing production data from tight oil wells. The Journal of Canadian Petroleum Technology, 50(5), 48-58.

Kah, M. (2018). Uncertainties in forecasting U.S. tight oil production. Columbia Center on Global Energy Policy, p. 3. h ttp://energypolicy.columbia.edu. Accessed 13 February 2019.

Kennedy, P. (2008). A guide to econometrics (6th ed.). WileyBlackwell.

Kenton, W. (2021). Solow residual. Investopedia. https://www.inve stopedia.com/terms/s/solow-residual.asp. Accessed 24 June 2021.

Kleinberg, R., Paltsev, S., Ebinger, C., Hobbs, D., \& Boersma, T. (2016). Tight oil development economics: benchmarks, breakeven points, and inelasticities. MIT Center for Energy and Environmental Policy Research Working Paper CEEPR WP 2016-012. http://ceepr.mit.edu/files/papers/2016-012.pdf. Accessed 9 April 2020.

Kleit, A., Leelachutipong, E., \& Wand, J. Y. (2020). Estimating the value of a unitization law for shale gas development. Journal of Energy Resources Technology, 142(4), 906.

Kramer, B. M. (2015). Unitization: A partial solution to the issues raised by horizontal well development in shale plays. $\mathrm{Ar}$ kansas Law Review, 68, 295-320.

Kumar, D. K., \& Hiller, J. (2020). U.S. shale companies to boost oil output by 500,000 bpd by month-end. Reuters. https://ww w.reuters.com/article/us-global-oil-usa-production-graphics/u s-shale-companies-to-boost-oil-output-by-500000-bpd-by-mo nth-end-idUSKBN23O2OQ. Accessed 20 June 2020.

LaFollette, R. F. (2013). Shale gas and light tight oil reservoir production results: What matters? In Proceedings of the 23rd international offshore and polar engineering conference, 5460, Anchorage, AK (June 30-July 5).

Luo, H., Li, H., Zhang, J., Wang, J., Wang, K., Xia, T., \& Zhu, X. (2018). Production performance analysis of fractured horizontal well in tight oil reservoir. Journal of Petroleum Exploration and Production Technology, 8(1), 229-247.

Mackrael, K., Blunt, K., \& Frosch, D. (2020). Oil price rout to hit U.S. regional economies. Wall Street Journal. https://www. wsj.com/articles/oil-price-rout-to-hit-u-s-regional-economies11587508075. Accessed 27 February 2021.

Mandy, D. (2017). Producers, consumers, and partial equilibrium. Elsevier Inc.

Market Watch. (2021). Hydraulic fracturing proppants market size, cost analysis, revenue and gross margin analysis with its important types and application to 2027. Press release available at https://www.marketwatch.com/press-release/hydrauli c-fracturing-proppants-market-size-cost-analysis-revenue-an d-gross-margin-analysis-with-its-important-types-and-applica tion-to-2027-2021-06-14. Accessed 24 June 2021.

Melek, N., Plante, M., \& Yücel, M. (2020). Resource booms and the macroeconomy: The case of U.S. shale oil. Review of Economic Dynamics. https://doi.org/10.1016/j.red.2020.11.00 6.

Montgomery, J. B., \& O’Sullivan, F. M. (2017). Spatial variability of tight oil well productivity and the impact of technology. Applied Energy, 195, 344-355.

Mork, K. (1994). Business cycles and the oil market. Energy Journal, 15, 15-38.

NASDAQ. (n.d.). SPDR $S \& P$ oil and gas explor and product $(X O P)$. https://www.nasdaq.com/market-activity/funds-and-e tfs/xop. Accessed 11 August 2021.

NDIC. (n.d.a). North Dakota general statistics. North Dakota Industrial Commission, Department of Mineral Resources, Oil and Gas Division. https://www.dmr.nd.gov/oilgas/stats/sta tisticsvw.asp. Accessed 27 February 2021. 
NDIC. (n.d.b). Various files. North Dakota Industrial Commission, Department of Mineral Resources, Oil and Gas Division. https://www.dmr.nd.gov/oilgas/. Accessed 9 September 2019.

NDIC. (n.d.c). Bakken horizontal wells by producing zone. North Dakota Industrial Commission, Department of Mineral Resources, Oil and Gas Division. https://www.dmr.nd.gov/oilga s/bakkenwells.asp. Accessed 27 February 2021.

NETL. (2011). Bakken: the biggest oil resource in the United States? National Energy Technology Laboratory, E\&P Focus, Oil and Natural Gas Program Newsletter (Winter). https:// undeerc.org/bakken/pdfs/EPNews2011Winter2.pdf. Accessed 22 July 2020.

Newell, R. G., Prest, B. C., \& Vissing, A. (2016). Trophy hunting vs. manufacturing energy: The price-responsiveness of shale gas. Discussion Paper RFF DP 16-32, Resources for the Future (August). https://media.rff.org/archive/files/documen t/file/RFF-DP-16-32.pdf. Accessed 27 February 2021.

Ngai, C., Jeffers, M., \& Crowley, K. (2019). Peak shale: How U.S. oil output went from explosive to sluggish. Bloomberg Business. https://www.bloomberg.com/news/articles/2019-1014/peak-shale-how-u-s-oil-output-went-from-explosive-to-slu ggish. Accessed 22 July 2020.

Pang, W., Ehlig-Economides, C. A., Du, J., He, Y., \& Zhang, T. (2015). Effect of well interference on shale gas well SRV interpretation. In SPE-176910-MS, SPE Asia Pacific unconventional resources conference and exhibition, Brisbane, Australia (November 9-11).

Pilcher, R. S., Ciosek, J. M., McArthur, K., Hohman, J., \& Schmitz, P. J. (2011). Ranking production potential based on key geological drivers-Bakken case study. In International petroleum technology conference, IPTC 14733, Bangkok, Thailand (February 7-9, 2012).

Sanderson, S., Bonny, T., Slaughter, A., Mittal, A., \& Bansal, V. (2019). Deciphering the performance puzzle in shales: moving the U.S. shale revolution forward. Deloitte Insights. http s://www2.deloitte.com/us/en/insights/industry/oil-and-gas/us-s hale-revolution-playbook/introduction-shale-performance-pr oductivity.html. Accessed 22 July 2020.

Smith, J. (2018). Estimating the future supply of shale oil: A Bakken case study. Energy Economics, 69, 395-403.

Smith, J., \& Lee, T. (2017). The price elasticity of U.S. shale oil reserves. Energy Economics, 67, 121-135.

Smith, V. K. (1981). The empirical relevance of Hotelling's model for natural resources. Resources and Energy, 3(2), 105-117.

Solow, R. M. (1956). A contribution to the theory of economic growth. Quarterly Journal of Economics, 70(1), 65-94.
StataCorp LLC. (n.d.). https://www.stata.com/company. Accessed 27 February 2021.

Theloy, C., \& Sonnenberg, S. A. (2013). New insights into the Bakken play: what factors control production. In Annual convention and exposition. American association of petroleum geologists, Pittsburgh, PA (May 19-23). http://www.sea rchanddiscovery.com/pdfz/documents/2013/80332theloy/ndx theloy.pdf.html. Accessed 22 July 2020.

Torres-Reyna, O. (2007). Panel data analysis, fixed and random effects using Stata (v. 4.2). Training presentation, Princeton University. https://www.princeton.edu/ otorres/Panel101.pdf . Accessed 28 February 2021.

USGS. (n.d.). Public land survey system (PLSS). U.S. Geological Survey. https://www.usgs.gov/media/images/public-land-surve y-system-plss. Accessed 28 February 2021.

Vatter, M. (2017). OPEC's kinked demand curve. Energy Economics, 63, 272-287.

Vatter, M. (2021). Pricing climate change as a mortal threat: Energy, COVID, and climate change. In Conference of the international association for energy economics. http://www.ia ee.org/proceedings/article/17059. Accessed 11 August 2021.

Weisstein, E. (n.d.). Wolfram Mathworld ${ }^{\circledR}$. Wolfram Research Inc. http://mathworld.wolfram.com/GeometricSeries.html. Accessed 20 March 2019.

Yang, X., Guo, B., \& Zhang, X. (2019). An analytical model for capturing the decline of fracture conductivity in the Tuscaloosa Marine Shale trend from production data. Energies, 12, 1938.

Zhang, H. E, Nelson, E., Olds, D., Rietz, D., \& Lee, W. J. (2016). Effective applications of extended exponential decline curve analysis to both conventional and unconventional reservoirs. In SPE 181536-MS, Society of petroleum engineer annual technical conference and exhibition, DUBAI, UAE (September 26-28).

Zhang, X.-S., Wang, H.-J., Ma, F., Sun, X.-C., Zhang, Y., \& Song, Z.-H. (2016b). Classification and characteristics of tight oil plays. Petroleum Science, 13, 18-33.

Zhou, P., Sang, H., Jin, L., \& Lee, J. (2017). Application of statistical methods to predict production from liquid-rich shale reservoirs. In URTeC 2694668, unconventional resources technology conference, Austin, TX (July 24-26)..

Zzhabf A. Annual Convention and Exposition, American Association of Petroleum Geologists, Pittsburgh, PA (May 19-23), http://www.searchanddiscovery.com/pdfz/documents/2013/80 332theloy/ndx_theloy.pdf.html, accessed July 22, 2020. 